\title{
Isolation, genetic manipulation, and transplantation of canine spermatogonial stem cells: progress toward transgenesis through the male germ-line
}

\author{
Michael A Harkey, Atsushi Asano ${ }^{1,2}$, Mary Ellen Zoulas ${ }^{3}$, Beverly Torok-Storb, \\ Jennifer Nagashima ${ }^{1,2}$ and Alexander Travis ${ }^{1,2}$
}

Clinical Research, Division, Fred Hutchinson Cancer Research Center, Mail Stop D1-100, 1100 Fairview Avenue North, PO Box 19024, Seattle, Washington 98109-1024, USA, ${ }^{1}$ College of Veterinary Medicine, Baker Institute for Animal Health, Cornell University, Ithaca, New York 14853, USA, ${ }^{2}$ Joint Graduate Training Program with the Smithsonian Conservation Biology Institute, National Zoological Park, Washington, District of Columbia 20008, USA and ${ }^{3}$ Seattle Animal Shelter Spay and Neuter Clinic, 2061 15th Avenue, West Seattle, Washington 98119, USA

Correspondence should be addressed to M A Harkey; Email: mharkey@fhcrc.org

\begin{abstract}
The dog is recognized as a highly predictive model for preclinical research. Its size, life span, physiology, and genetics more closely match human parameters than do those of the mouse model. Investigations of the genetic basis of disease and of new regenerative treatments have frequently taken advantage of canine models. However, full utility of this model has not been realized because of the lack of easy transgenesis. Blastocyst-mediated transgenic technology developed in mice has been very slow to translate to larger animals, and somatic cell nuclear transfer remains technically challenging, expensive, and low yield. Spermatogonial stem cell (SSC) transplantation, which does not involve manipulation of ova or blastocysts, has proven to be an effective alternative approach for generating transgenic offspring in rodents and in some large animals. Our recent demonstration that canine testis cells can engraft in a host testis, and generate donorderived sperm, suggests that SSC transplantation may offer a similar avenue to transgenesis in the canine model. Here, we explore the potential of SSC transplantation in dogs as a means of generating canine transgenic models for preclinical models of genetic diseases. Specifically, we i) established markers for identification and tracking canine spermatogonial cells; ii) established methods for enrichment and genetic manipulation of these cells; iii) described their behavior in culture; and iv) demonstrated engraftment of genetically manipulated SSC and production of transgenic sperm. These findings help to set the stage for generation of transgenic canine models via SSC transplantation.

Reproduction (2013) 146 75-90
\end{abstract}

\section{Introduction}

Spermatogonial stem cells (SSC) are the stem cells in testis that generate spermatozoa throughout the adult life of the males. As with all true stem cells, SSC can undergo both self-renewal and differentiation divisions, thereby maintaining a static population of stem cells, while generating a constant supply of spermatozoa. In mice, these cells can be isolated and expanded indefinitely without genetic drift or loss of stem cell potential (Shinohara \& Brinster 2000, Shinohara et al. 2000a, 2000b, Kanatsu-Shinohara et al. 2003, 2005, Nagano et al. 2003, Kubota et al. 2004, Hamra et al. 2005, 2008, Oatley \& Brinster 2006, 2008, Oatley et al. 2010). They can be genetically manipulated efficiently by transduction and transfection (Kanatsu-Shinohara et al. 2004, 2006, 2011, Hamra et al. 2005, Kanatsu-Shinohara \& Shinohara 2007, Takehashi et al. 2010). SSC provide an alternative approach for the generation of transgenic mice. When transplanted into the testes of sterile male mice, SSC efficiently repopulate the seminiferous tissue and reinitiate spermatogenesis. The offspring of these males carry the genetic properties of the donor cells (Kanatsu-Shinohara et al. 2004, 2006, 2011, KanatsuShinohara \& Shinohara 2007, Takehashi et al. 2010). Mouse SSC can also be converted into pluripotent cells, without genetic manipulation (Guan et al. 2006, Conrad et al. 2008, Izadyar et al. 2008, Golestaneh et al. 2009b, Mizrak et al. 2010). These germ-line-derived pluripotent stem cells (gPS) acquire an expression profile similar to embryonic stem cells (ESCs; Silva et al. 2009) and are functionally indistinguishable from ESC: they form complex teratomas, differentiate into three germ layers in culture, and contribute to all the tissues of mice generated from chimeric blastocysts (Takehashi et al. 2007, Conrad et al. 2008, Izadyar et al. 2008). Thus, at 
least in the mouse, SSCs provide an unusually versatile source of material for stem cell and developmental research, including transgenic animal technology and stem cell-based cell therapy.

It would be extremely valuable to translate this technology to large animals for modeling human diseases. The SSC could be used directly to generate transgenic animal models for preclinical research, and the gPS would serve to bypass both the ethical concerns regarding ESC and the potential of genetic anomalies created in the multi-gene insertion approaches to generating 'induced PS' (iPS) cells. Other approaches to transgenic models in large animals have been very difficult and inefficient. While multiple lines of canine (Hayes et al. 2008, Wilcox et al. 2009) and other large animal (Kumar De et al. 2011, Vassiliev et al. 2011, Kim et al. 2012) ESCs have been reported, all non-rodent lines tend to show genetic drift and loss of pluripotency over time (Yang et al. 2010, Gerwe et al. 2011). In addition, demonstration of germ-line transmission and generation of transgenic large animal models from ESC have been largely unsuccessful. Genetically, chimeric pigs have been produced recently (West et al. 2010) by implanting iPS into early embryos, but this approach has not yet succeeded in other large animals. Several transgenic dogs (Hong et al. 2009, 2011) and other large animal models (An et al. 2012, Giraldo et al. 2012, Jung et al. 2013) have been generated through somatic nuclear transfer but, so far, this approach has been extremely labor, cost, and animal intensive.

Several authors have reported isolation and short-term culture of spermatogonia (SPG) from large animals (Kim et al. 2006, Rodriguez-Sosa et al. 2006, Goel et al. 2007, Hermann et al. 2007, Aponte et al. 2008) and humans (Wu et al. 2009a), as well as conversion of these cells into gPS cells (Golestaneh et al. 2009b). SSC transplantation and subsequent donor sperm production has now been reported in pigs, sheep, bulls, goats, monkeys, and dogs (Izadyar et al. 2003, Kim et al. 2008, Herrid et al. 2011, Jahnukainen et al. 2011, Hermann et al. 2012, Zeng et al. 2012, 2013). More importantly, SSC transplants in both sheep (Herrid et al. 2009) and goats (Honaramooz et al. 2003) have led to the birth of donorderived offspring through normal mating. So this technology is clearly applicable to large animals.

In this light, the canine has major potential as a preclinical transgenic model for two major reasons. First, research with the canine model has proven to be highly translatable to the clinical setting. This model better reflects the size, life span, physiology, and genetics of humans than does the mouse model (Tsai et al. 2007). The canine model is also much more cost-effective than primate models. It is a primary preclinical model for hematopoietic stem cell transplantation (Lupu \& Storb 2007), gene therapy (Nowend et al. 2011,
Okazuka et al. 2011), and cancer research (Gordon \& Khanna 2010, Rowell et al. 2011). The dog displays a large repertoire of naturally occurring genetic diseases with human counterparts (Athanasiou et al. 1995, Lingaas et al. 2003, Acland et al. 2005), and where data are available, the same genes are involved in both species (Tsai et al. 2007). Secondly, the ability of canine SSC to engraft and reinitiate spermatogenesis in a recipient testis has been demonstrated (Kim et al. 2008). So far, canine SSC activity has only been shown in freshly prepared, unfractionated testis cells. It remains to be demonstrated that canine SSC can retain engraftment potential after purification, genetic manipulation, culture, and cryopreservation.

Here, we describe, for the first time, the identification, isolation, culture, and genetic manipulation of canine SSC. We demonstrate engraftment and generation of mature transgenic sperm by canine SSC transplanted into the testes of recipient males. A true SSC can only be distinguished from committed and differentiating SPG by its ability to engraft. Therefore, the term 'SSC' will be reserved henceforth for true stem cells, while the more general term 'SPG' will be used when that distinction is not verifiable.

\section{Materials and methods}

\section{Reagents}

Hanks' balanced salt solution (HBSS; cat \#14175), penicillin/streptomycin (15140-122), B27-vitamin A supplement (12587-010), trypsin-EDTA (25200-056), Superscript II reverse transcriptase (18064-014), all Alexa-tagged secondary antibodies (Supplementary Table 1), dispase (17105-041), dispase (17105-041), mouse LIF (LIF2005), and heat-inactivated FBS (10082147) were from Invitrogen. Biosprint 96 blood DNA isolation kits (940057), and RNAeasy RNA isolation mini kits (74104) were from Qiagen. Type 4 collagenase (LS004212) and hyaluronidase (LS005475) were from Worthington (Lakewood, NJ, USA). Primary antibodies were purchased as indicated in Supplementary Table 1. DMEM/F12 medium (SH30023.01) and buffered formalin (SF98-4) were from Fisher Scientific (Waltham, MA, USA). Primer synthesis was done by Operon (Huntsville, AI, USA). Trypsin (T4799), DNase I (D4513-1 VL), laminin (L2020), gelatin (G1890-100G), L-glutamine (G639210L), BSA (A9576-50ml), donkey serum (D9663-10ML), and human FGF2 (F0291-25UG) were from Sigma. Advantage 2 polymerase mix (639202) was from Clontech. Human EGF (354052) was from BD Biosciences (San Jose, CA, USA). Human GDNF (212-GD050) was from Roche Biochemicals. Rat soluble GFRA1 (560-GR-100), human BDNF (284-BD-025), human NT3 (267-N3-025), human NT4 (268-N4-025), human Pleiotropin (252-PL-250), and human WNT3A (5036-WIN010) were from R\&D Systems (Minneapolis, MN, USA). 
Target retrieval solution (S1699) was from DAKO (Carpinteria, CA, USA). Falcon tissue culture flasks and plates were from BD Biosciences.

\section{Canine testis tissues}

Testes were obtained from the Seattle Spay and Neuter Clinic immediately following routine neutering for unrelated purposes. Tissue was collected from a variety of breeds in the age range of 3-12 months. Testes were transported in sterile Hanks buffered saline on ice and used within $2 \mathrm{~h}$ of castration.

\section{Isolation and culture of SPG}

Testes from 3- to 5-month-old (prepubertal) dogs were washed twice in fresh, sterile HBSS. The testis parenchyma, containing the testicular cords, was dissected away from the tunica vaginalis and tunica albuginea, epididymis, and other non-seminiferous tissue, washed twice in HBSS, minced to $<1 \mathrm{~mm}$ pieces, and digested for $30 \mathrm{~min}$ at $37^{\circ} \mathrm{C}$ in $30 \mathrm{ml} \mathrm{DMEM} / \mathrm{F} 12$ medium containing $1 \mathrm{mg} / \mathrm{ml}$ type 4 collagenase and $33 \mu \mathrm{g} / \mathrm{ml}$ DNase I. Tissue was dispersed into single cells and small lengths of cords by vigorous pipetting and then filtered through sterile gauze. The filtrate was washed twice in HBSS by centrifugation at $200 \mathrm{~g}$ for $5 \mathrm{~min}$. The washed cells and cord segments were plated in $225 \mathrm{~cm}^{2}$ culture flasks at an estimated $5 \times 10^{7}$ cells/flask in DMEM/F12 medium containing $10 \% \mathrm{FBS}, 50$ units/ml penicillin, and $50 \mu \mathrm{g} / \mathrm{ml}$ streptomycin. At 3 days of culture, dead cells were removed by replacing the medium with HBSS. Loose cells were then dislodged from the tissue culture layer by 15-20 vigorous horizontal raps of the flask against a styrofoam block. The loose cells were pooled and selected for non-adhesion to gelatin by two rounds of plating for $2 \mathrm{~h}$ on a gelatin-coated $10 \mathrm{~cm}$ tissue culture dish and re-collection of all non-adherent cells. The remaining loose cells were either used directly for analysis or cryopreserved under liquid nitrogen in $70 \%$ DMEM/F12, 20\% FBS, and 10\% DMSO. Cells were cultured in either of two basic media: i) complete DMEM/F12: DMEM/F12 with 10\% FBS and Pen/Strep or ii) SG: a serum-free medium optimized for rat SSC culture (Wu et al. 2009b). Additional modifications to the culture conditions, including substratum, feeder cells, serum level, and growth factors, are specified in Supplementary Table 2, see section on supplementary data given at the end of this article. Mouse embryonic feeder cells were expanded from 14-day mouse embryos, mitotically inactivated by $\gamma$ irradiation $(3000$ Rad), and plated at 25000 cells $/ \mathrm{cm}^{2} 1$ day before addition of SPG. Testis fibroblast feeder cells were adherent cells from 3-month-old canine testis, expanded for at least three passages, and at least 10 days of constant culture, then irradiated at $3000 \mathrm{Rad}$, and plated at 25000 cells $/ \mathrm{cm}^{2} 1$ day before addition of SPG. Cultures were maintained at $37^{\circ} \mathrm{C}$ in a humidified tissue culture incubator with $5 \% \mathrm{CO}_{2}$ and media were changed every $48 \mathrm{~h}$.

\section{Lentiviral constructs}

Self-inactivating lentiviral reporter construct, PL-SINEF1a-EGFP (Hotta et al. 2009), driven by the widely expressed mouse EF1 $\alpha$ promoter, was purchased from Addgene (http://www.addgene.org). A second selfinactivating lentiviral construct carrying a widely expressed PGK-mCherry reporter (pRCH-PCh-W) was obtained from the Viral Vector Production Core at Fred Hutchinson Cancer Research Center. Packaging vector, psPAX2 (plasmid 12260) and vsv-G envelope vector, pMD2.G (plasmid 12259), were from the Trono Lab and purchased from Addgene (http://www.addgene. org/Didier_Trono).

\section{Lentiviral transduction of SPG}

PL-SIN-EF1a-EGFP and pRCH-PCh-W were packaged in HEK293 cells as VSVG-pseudotyped lentiviral particles according to Addgene protocol E.2, filtered through a $0.45 \mu \mathrm{M}$ filter (Millipore, Billerica, MA, USA), concentrated by centrifugation at $13000 \mathrm{~g}$ for $15 \mathrm{~h}$, and stored in aliquots at $-80^{\circ} \mathrm{C}$. Infectious particle concentrations were determined by titered infection of HEK293 cells (15-h transduction in the presence of $4 \mu \mathrm{g} / \mathrm{ml}$ polybreen on $70 \%$ confluent cells), followed by determination of percentage of reporter-expressing cells at $48 \mathrm{~h}$ postinfection. Final titers were $1-2 \times 10^{7}$ infectious units $/ \mathrm{ml}$. Transduction of freshly isolated SPG (loose cells) was performed by incubating $0.5-2 \times 10^{6}$ cells with virus $(\mathrm{MOI}=5-15)$ in $1 \mathrm{ml}$ transduction medium (DMEM/F12/ $10 \% \mathrm{FBS} / 4 \mu \mathrm{g} / \mathrm{ml}$ polybreen) for $15 \mathrm{~h}$ in a tissue culture incubator. Cells were then washed twice with HBSS and plated in SG medium. Expression of reporter genes was monitored by flow cytometry and by epifluorescence microscopy.

\section{Histology and immunohistochemistry}

Seminiferous tissue was cut into $1 \mathrm{~cm}$ cubes, fixed for $72 \mathrm{~h}$ in buffered formalin, embedded in paraffin, and sectioned at $1.5 \mu \mathrm{m}$ thickness. Sections were deparaffinized in three washes of xylene, rehydrated through an ethanol series $(100,100,85,70 \%$, and water), and washed twice in TBST $(50 \mathrm{mM}$ Tris, $150 \mathrm{mM} \mathrm{NaCl}$, and $0.1 \%$ Tween 20, $\mathrm{pH} 7.6$ ) for 10-min intervals. Antigen retrieval was performed by a 20 -min incubation at $95{ }^{\circ} \mathrm{C}$ in a pre-warmed target retrieval buffer (DAKO) followed by three washes in HBSS. Treated sections were incubated for $30 \mathrm{~min}$ in blocking buffer (TBST $+5 \%$ BSA and $5 \%$ Donkey serum) and then for $15 \mathrm{~h}$ at $4{ }^{\circ} \mathrm{C}$ in 
blocking buffer plus primary antibody (see Supplementary Table 1 for antibodies and concentrations). Sections were washed $5 \times 3 \mathrm{~min}$ in TBST, incubated $2 \mathrm{~h}$ at RT in a $1000 \times$ dilution of an appropriate Alexa Fluortagged donkey secondary antibody (Supplementary Table 1) in TBST, washed similarly, and observed by epifluorescent microscopy. Cultured cells were fixed on the plate for $20 \mathrm{~min}$ in $10 \%$ buffered formalin and probed as described for post-antigen retrieval sections. DBAmediated localization of $\alpha$-D- $N$-acetyl-galactosamine was performed as described (Izadyar et al. 2002).

\section{Microscopy}

Phase and epifluorescent microscopy were done on an Eclipse Ti-U inverted microscope equipped with several phase lenses, a TI-FL Epi-fl epi-illumination system, and digital DS-Qi1Mc monochrome camera (Nikon). Images were recorded and pseudo-colored using NIS-Elements D3.2 Software from Nikon and color-merged with Photoshop Software (Adobe).

\section{Flow cytometry analysis}

For dual reporter expression studies, cells were washed twice with HBSS, dissociated with trypsin-EDTA for 5 min at room temperature, washed twice with HBSS, and observed by flow cytometry on a FACS Calibur flow cytometer (BD Biosciences). For comparison of GFP reporter expression to VASA immunolocalization, cells were washed twice with HBSS, dissociated with trypsinEDTA for $5 \mathrm{~min}$ at room temperature, fixed for $5 \mathrm{~min}$ in $10 \%$ buffered formalin, washed three times in HBSS, blocked 10 min in blocking buffer, incubated at RT for $1 \mathrm{~h}$ in blocking buffer containing anti-VASA antibody (Supplementary Table 1) at $100 \times$ dilution, re-washed and incubated with donkey anti-rabbit-Alexa-594 secondary antibody (Supplementary Table 1), rewashed, and observed by flow cytometry as earlier. All washes were performed by re-suspension in HBSS and centrifugation at $200 \mathrm{~g}$ for $5 \mathrm{~min}$.

\section{RT-PCR analysis of gene expression}

Three separate experiments were performed using dissociated testicular cells from three different prepubertal dogs: a 16-week-old Black Labrador and two 10-week-old German Shepherd littermates. For each testis sample, RNA was extracted from intact seminiferous tissue at day 0 , from the total cultured cells at 3 days, from the 'loose' and adherent cell populations isolated at day 3 , and from duplicate loose and adherent populations after 30 days in culture. RNA from testis tissue and cultured cells was extracted using an RNeasy mini kit (Qiagen) according to the manufacturer's instructions and quantitated by u.v. spectral analysis using a
Nanodrop 1000 spectrophotometer (ThermoFisher Scientific, Inc., Wilmington, DE, USA). Two micrograms of RNA were reverse transcribed using oligo-dT18 primers and Superscript II Reverse Transcriptase (Invitrogen) according to the manufacturer's instructions. Before expression analysis, cDNAs were normalized to $\beta$-actin (ACTB) by adjusting the cDNA concentrations until they gave similar signals by ACTB RT-PCR. The adjusted cDNAs were used for all subsequent expression analysis. Primers for amplification of each specific mRNA target (Supplementary Table 3, see section on supplementary data given at the end of this article) were designed to amplify a region spanning one or more introns of significant size, thus eliminating false-positive signals from contaminating genomic DNA. Each primer pair was verified by cloning and sequencing the product amplified from testis cDNA. Primers were designed with a $\mathrm{Tm}$ of $72-74{ }^{\circ} \mathrm{C}$ to accommodate a uniform two-step cycle of $20 \mathrm{~s}$ at $94{ }^{\circ} \mathrm{C}$ and $2 \mathrm{~min}$ at $68^{\circ} \mathrm{C}$. Amplifications were performed as $20 \mu \mathrm{l}$ reactions containing $2 \mu \mathrm{l}$ normalized cDNA, primers at $200 \mathrm{nM}$, dNTPs at $200 \mu \mathrm{M}$, and Advantage 2 polymerase mix and buffer. Products were separated by agarose, gel electrophoresis, and detected by ethidium bromide staining.

\section{Transplantation of SSC}

Several preparations of donor SPG (Supplementary Table 4) were prepared and transduced with lentivirus, as described earlier, washed in serum-free and growth factor-free SG medium, and cryopreserved in SG/20\% $\mathrm{BSA} / 10 \%$ DMSO. On the day of transplantation, each cell preparation was thawed, washed three times in DMEM/F12, re-suspended in $1 \mathrm{ml}$ DMEM/F12, and held at $4{ }^{\circ} \mathrm{C}$ until use $(1-3 \mathrm{~h})$. Transplantation of SPG and all animal care and handling were done at Cornell University, and all related protocols were reviewed and approved by the Institutional Animal Care and Use Committee of Cornell University. Three 5-month-old hounds (Marshall BioResources, North Rose, NY, USA) had their testes subjected to focal external beam radiation to deplete their endogenous germ cells as described (Kim et al. 2008), except that the irradiation regimen was reduced from three consecutive days of 3 Gy/day, 8 weeks before transplant, to a single 3 Gy dose on the day of transplant. The smaller dose was designed to lower the apparently excessive toxicity to the testis tissues observed in our previous study, which had resulted in complete loss of libido and almost no recovery of testis size, histological evidence of spermatogenesis, or sperm count. One milliliter of medium containing $2-5 \times 10^{5} \mathrm{SPG}$ was injected in retrograde fashion into the rete testis under the guidance of ultrasound scanning (Aloka 633, Colormetrics Medical Systems, Inc., Wallingford, CT, USA) as described previously (Kim et al. 2008). 


\section{VNTR analysis of donor/recipient sperm production}

DNA was purified by silica binding from ejaculated sperm, using a Qiagen Biosprint magnetic bead DNA isolation kit, according to the manufacturer's instructions. Donor and recipient DNA standards were prepared respectively from testis tissue used to generate each SSC preparation and blood from pretransplant recipients. The contribution of recipient and donor sperm cells was quantified by fluorescent VNTR analysis of microsatellite loci, as described (Scharf et al. 1995, Hilgendorf et al. 2005) and modified (Graves et al. 2007). Microsatellite FH2001 was used to distinguish the DNA of recipients 795941 and 795917 from their respective donor cells. Microsatellites $\mathrm{FH} 2611$ and $\mathrm{FH} 2199$ were used to distinguish Recipient 795933 from its donor cells. The primers used for these VNTRs are listed in Supplementary

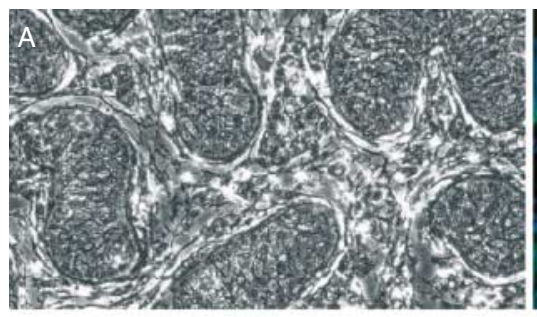

Phase

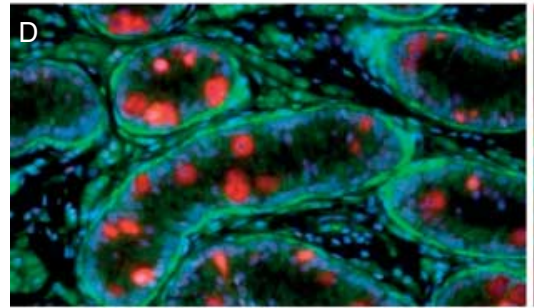

ACTA1 VASA DNA

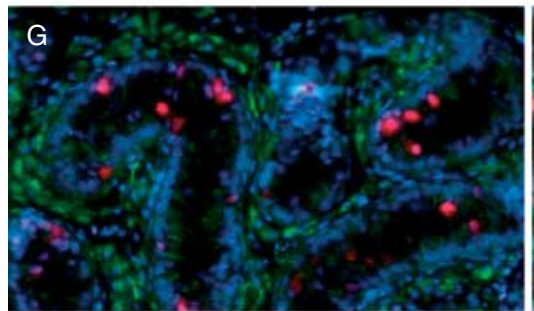

ACTA1 RET DNA

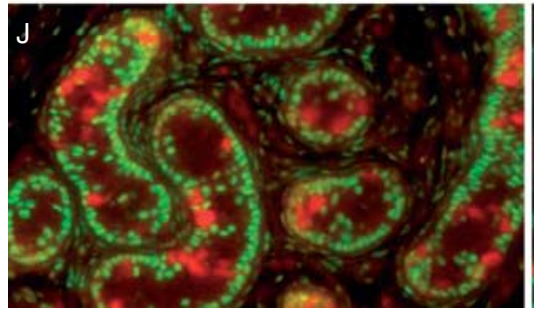

GATA4 AP180

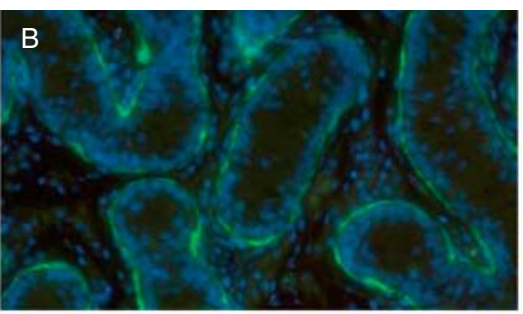

ACTA1 no primary DNA

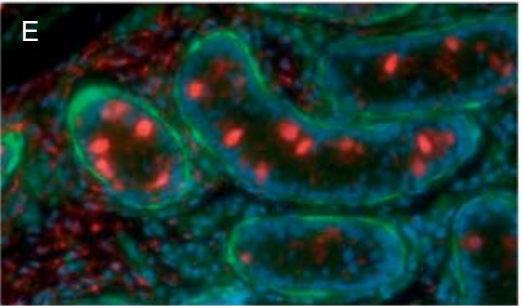

ACTA1 UCHL1 DNA

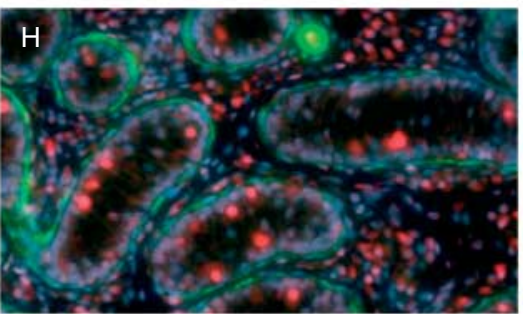

ACTA1 POUF5 DNA

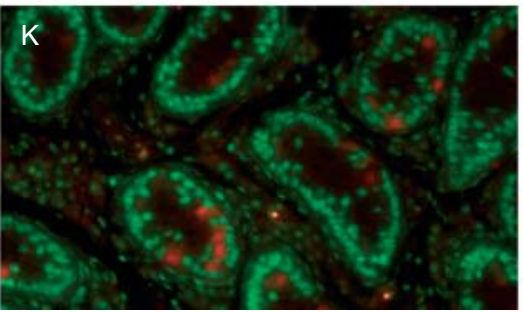

GATA4 PLZF

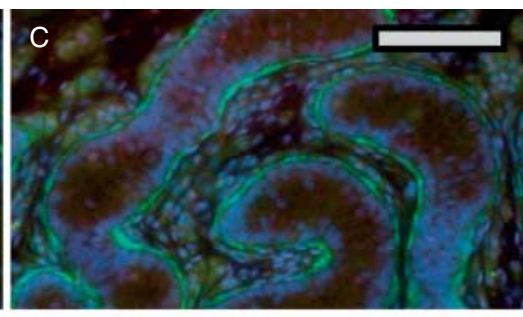

ACTA1 isotype cont DNA

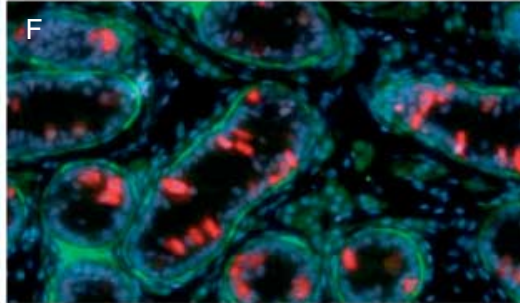

ACTA1 DAZL DNA

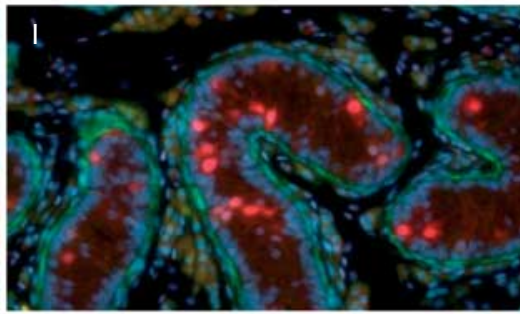

ACTA1 PLZF DNA

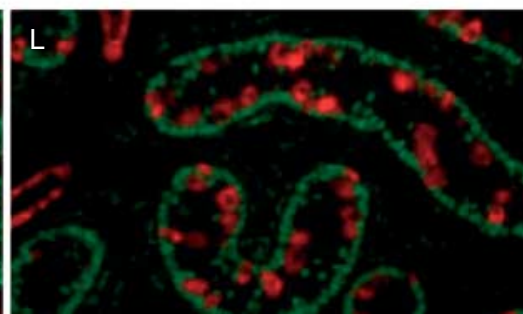

GATA4 VASA

Figure 1 Localization of SPG antigens in prepubertal caninetestis. (A) Phase image of tissueafter deparaffinization. (B, C, D, E, F, G, H, I, J, Kand L) Dual-label probes in which putative SPG antigens (red) and somatic cell antigens (green) were marked. Putative SPG antigens (red) were probed with either rabbit (C, D, E, F, G, H and I) or goat (J, K and L) primary antibodies as indicated, followed by the appropriate Alexa-594-conjugated donkey secondary antibody. Somatic cells (green) were labeled either with mixed mouse antibodies against $\alpha$-actin and vimentin, (B, C, D, E, F, G, H and I) or GATA4 (J, K and L) followed by an anti-mouse Alexa 488 conjugate. The specific antibodies and dilutions used are shown in Supplementary Table 1. Controls for background labeling were done identically except that they included either no primary antibody (B) or a rabbit isotype control (C). Specific antibodies and dilutions are listed in Supplementary Table 1. Nuclei were counterstained blue with Hoechst 33342 in some sections (B, C, D, E, F, G, H and I). Bar =100 $\mu$ m. 
Table 5, see section on supplementary data given at the end of this article. In all cases, standard curves showed a threshold of unequivocal detection of donor DNA at $1-2 \%$ of total.

\section{PCR detection of transgenic cells in sperm}

Sperm DNA was analyzed for the presence of PL-SINEF1a-EGFP sequence by PCR. Three distinct regions within the construct were amplified in separate reactions as a means of corroborating low signal reactions (see Supplementary Table 5 for primer sequences). Amplification was in $20 \mu \mathrm{l}$ reactions containing 100 ng DNA, $200 \mathrm{nM}$ primers, $200 \mu \mathrm{M}$ dNTPs, and $1 \times$ Advantage 2 polymerase mix and buffer. Reactions were run for 35-40 cycles under the two-step conditions used for RT-PCR. As standards for semiquantitative estimation of vector copy number, reactions were run simultaneously on a titration series of $0,20,60,200$, and 2000 copies of linearized PL-SIN-EF1a-EGFP plasmid (based on a plasmid size of 7601 bps and a calculated mass of 7.78 atograms/molecule) in $100 \mathrm{ng}$ canine DNA (estimated at 40000 haploid genomes, based on a haploid canine genome size of $2.5 \times 10^{9} \mathrm{bps}$ or $2.56 \mathrm{pg}$ (http:// www.genome.ucsc.edu/).

\section{Results}

\section{Establishment of molecular markers for canine SPG}

In order to identify and track canine SPG in culture, we screened a battery of commercially available antibodies to established murine and human SPG markers for specificity in canine prepubertal (4 months) testis. At this stage, the testicular cords present a simple architecture compared with mature testis (Nayernia et al. (2004); see Fig. 1A). Only two cell types, the gonocytes/SPG and Sertoli cells, are packed in the dense cord-like structures bound by a basement membrane. Both cell types are attached to the basement membrane at this age, but the Sertoli cell nuclei align along the periphery while the nuclei of the SPG are more centrally located (Nayernia et al. 2004). All SPG are SSC at this stage, as spermatogenesis has not yet started. Antibodies against reported SPG and SSC-specific target antigens VASA (Noce et al. 2001), UCHL1 (Goel et al. 2007), DAZL (Anderson et al. 2007), PLZF (Jijiwa et al. 2008), AP180 (von Kopylow et al. 2010), POUF5 (Anderson et al. 2007), and RET (Anderson et al. 2007, Tyagi et al. 2009) marked the interior SSC of canine prepubertal testis (Fig. 1). In contrast, ACTA1 was enriched outside of the cords in peri-tubular myoid and Leydig cells (Fig. 1B, C, D, E, F, G, H and I). GATA4, known as a Sertoli cell marker in mice (Ketola et al. 2002) and pigs (McCoard et al. 2001), was confined to the peripheral Sertoli nuclei of the cords (Fig. 1J, K and L). The VASA antibody was the most reliable probe for SSC, yielding a consistent, strong signal in all experiments. Dual-label staining demonstrated co-localization of VASA, UCHL1, DAZL, PLZF, and AP180 in the same set of interior cells (Supplementary Figure 1, see section on supplementary data given at the end of this article). Unfortunately, we were unable to demonstrate SSC-specific labeling by antibodies against established murine SSC surface antigens (data not shown), such as GFRA1, B1 and A6 integrins, and GPR125, each of which could be useful for immunofluorescent sorting of mouse SSC (Shinohara et al. 1999, Bjarnadottir et al. 2004, Grisanti et al. 2009). Localization of cRet, another SPG surface antigen in mice (Tyagi et al. 2009), was sporadic in prepubertal canine testis and appeared to be nuclear rather than cell surface (Fig. 1G). The reported localization of $\alpha$-D- $N$-acetyl-galactosamine on the surface of porcine (Goel et al. 2007) and bovine (Izadyar et al. 2002) SSC could also not be confirmed in the dog using a similar dolichos biflorus agglutinin (DBA) binding assay.

The same probes were used to localize SPG in mature testis (Fig. 2). As the testis matures, a central lumen forms

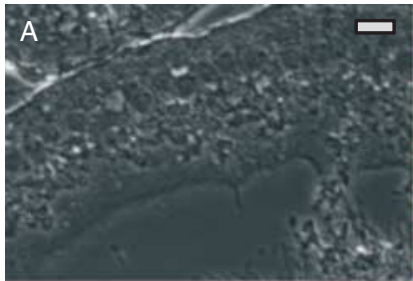

Phase

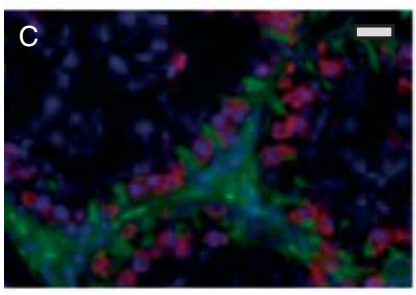

DAZL+ACTA1/VIM+DNA

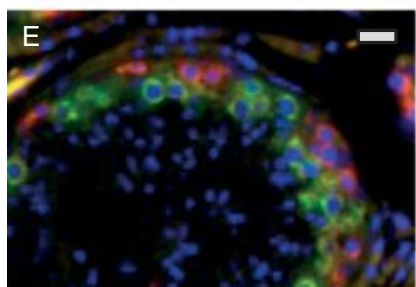

$D A Z L+V A S A+D N A$

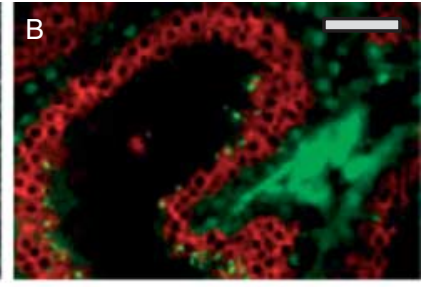

VASA+ACTA1/VIM

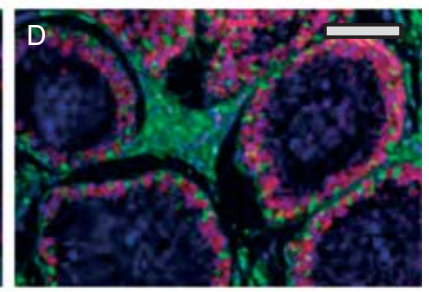

UCHL1+ACTA1/VIM+DNA

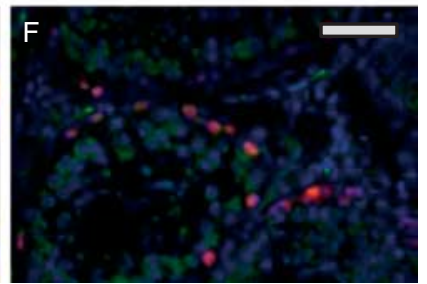

UCHL1+VASA+DNA
Figure 2 Localization of SPG antigens in adult canine testis. (A) Phase image of tissue after deparaffinization. (B, C and D) Dual-label probes in which putative SPG antigens (red) and somatic cell antigens (green) were marked. Putative SPG antigens (red) were probed with either rabbit (B) or goat (C and D) primary antibodies as indicated, followed by the appropriate Alexa-594-conjugated donkey secondary antibody. Somatic cells (green) were labeled with mixed mouse antibodies against $\alpha$-actin and vimentin, followed by an anti-mouse Alexa 488 conjugate. (E and F) Dual-label probes for two SPG antigens. Note that the UCHL1 staining intensity in (F) is much lower than in (D), showing only the most strongly positive cells. Bars $=150 \mu \mathrm{m}$. 
in the cords, creating seminiferous tubules. The SSCs are confined at the basement membrane by Sertoli cells. Successive advancing stages of male germ cell development (SPG, spermatocytes, spermatids, and spermatozoa) advance spatially toward the lumen, whereas Sertoli cell processes interdigitate among the male germ cells, supporting the developmental process (Nayernia et al. (2004); see Fig. 2A). Most of the SPG/SSC markers seen in prepubertal testis were more difficult to detect in mature testis. All immunofluorescence signals were lower in adults. However, VASA, UCHL1, and DAZL were clearly expressed in cells located either at the basement membranes of tubules, or in layers near these peripheral cells (Fig. 2B, C, D, E and F), consistent with SPGs and early stages of spermatogenesis. As detected by immunohistochemistry, VASA expression appeared to be higher in differentiating SPGs and spermatocytes than in the most peripheral cells, including the SSC (see Supplementary Figure 4, see section on supplementary data given at the end of this article). This pattern is similar to that seen in Human and Rhesus testis (Castrillon et al. 2000, Hermann et al. 2007). Thus, VASA may be a poor marker for adult canine SSC and a clear marker has not yet emerged. As indicated in Fig. 2E and F, DAZL and UCHL1 may detect earlier stages than VASA, but the identity of the positive cells is not yet clear.

\section{Isolation of canine SSC}

Prepubertal testes (3-6 months) were used as the source of SSC, taking advantage of the lower cellular complexity of the tissue at this stage. Spermatogenesis has not yet begun, and SSC are the only germ-lineage cells in the testes. In contrast to the mouse, a standard two-step digestion of canine prepubertal testis tissue with collagenase, followed by collagenase plus trypsin, and/or hyaluronidase (Hamra et al. 2008) did not generate a usable single-cell suspension. Considerable cell lysis was observed within the cords before the basement membrane dissociated. Thus, we chose a gentler collagenase-only digestion and plated incompletely digested pieces of seminiferous cords (Fig. 3A). By 3 days, most cells had migrated out of the cord structures onto the plate surface. Most of the VASA+ cells were rounded, loosely adherent cells that resided on top of a super-confluent layer of fibroblast-like cells (Figs $3 \mathrm{~B}$ and $\mathrm{C}, 4 \mathrm{~A})$. These VASA+ cells could be dislodged by vigorous agitation of the flask and harvested with the medium. The 'loose' cells were then further enriched by depleting collagen-adhesive cells (Hamra et al. 2008), with two rounds of short-term culture on gelatin-coated plates. The final preparation typically contained about $0.5-1 \times 10^{6}$ of $70 \%$ pure SPG, as judged by VASA immunohistochemistry (Fig. 4B) and by flow cytometry (Fig. 4C). Before enrichment, $<3 \%$ of cells were VASA-positive, indicating an enrichment of about 23-fold. Cryopreservation of the enriched cells,
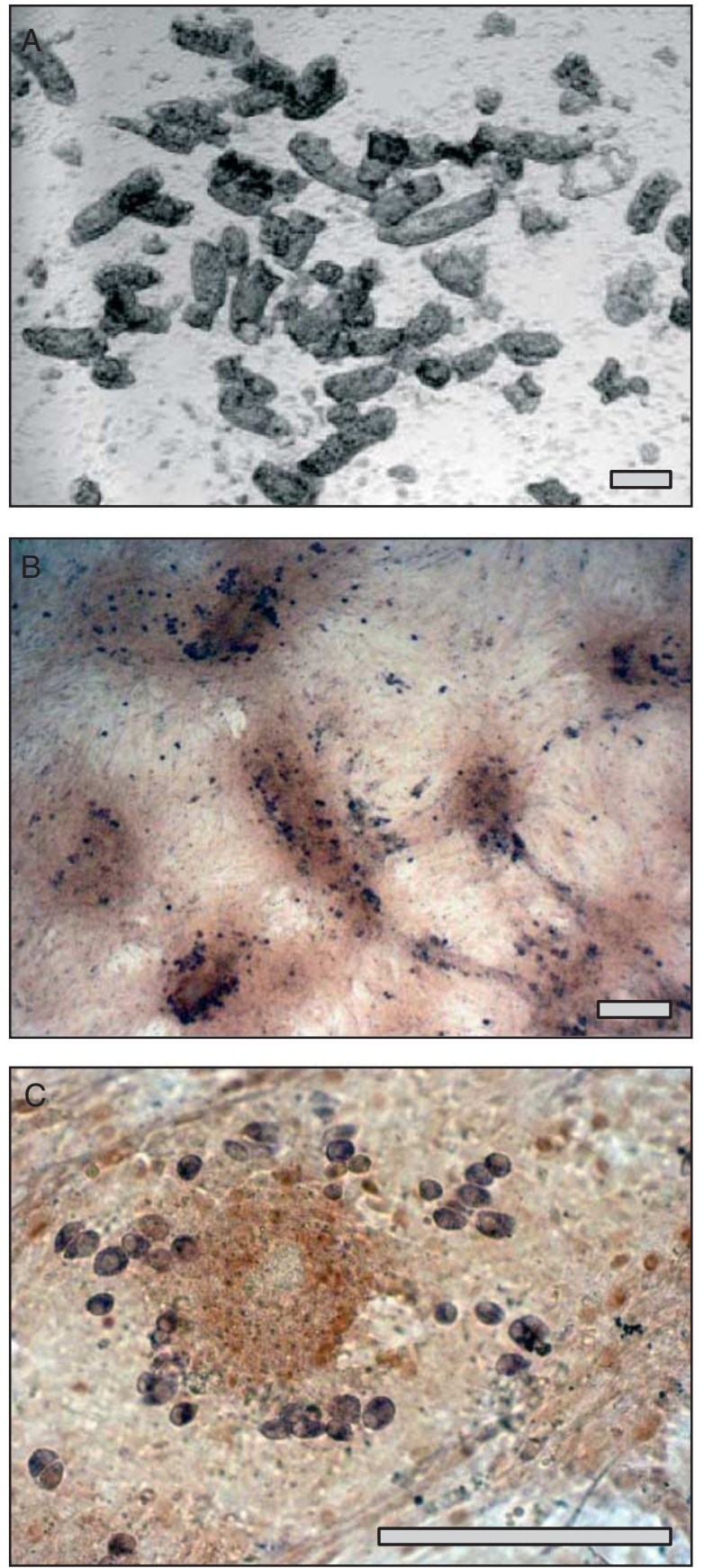

Figure 3 Emergence of SPG as a 'loose cell' population in cultures of total testis cells. (A) Bright field image of partially digested seminiferous tubules used to initiate culture. (B) Immunohistochemistry for VASA (purple) and GATA4 after 3-day culture of total testis cells. Note remnants of tubule pieces (dark brown) are firmly attached to substratum. (C) Higher power image of culture shown in (B). The VASA-positive cells are rounded and loosely scattered on top of the dense fibroblast-like lawn. Bars $=100 \mu \mathrm{m}$.

followed by thawing and washing, resulted in about $70 \%$ viability, based on trypan blue exclusion. RT-PCR analysis of several SPG markers confirmed the enrichment of SPGs (Fig. 4D). Canine homolog mRNAs of the well-established mouse SPG markers, DAZL, AP180, 

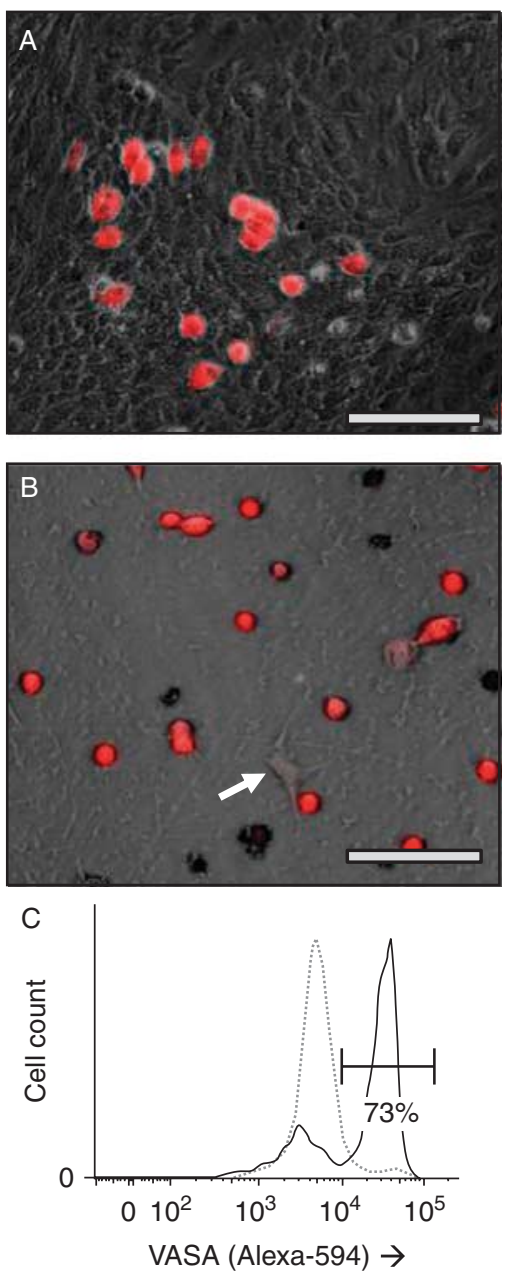

D
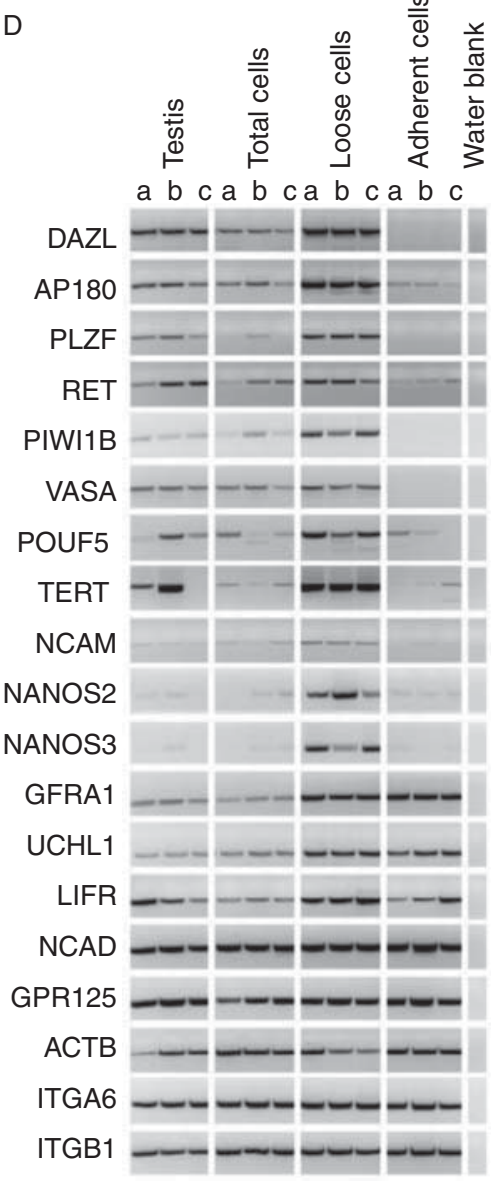

Figure 4 Enrichment of SPG by differential adhesion. (A) Composite phase/fluorescent image of 3-day testis cell culture before harvest of SPG. VASA-positive cells are shown in red. (B) Final preparation of SPG after harvest of 'loose' cells from 3-day culture and two rounds of differential adhesion to gelatin. The isolated cells were allowed to adhere to a laminin surface and were then probed for VASA by immunofluorescence. The arrow indicates a VASA-negative fibroblast. (C) FLOW data showing VASA immunofluorescence before and after enrichment of SPG by differential adhesion. Dotted line: unfractionated testis cells, collected at day 3 of culture, before removal of 'loose' cells. Cells (which had fully emerged from tubule structures by this time) were re-suspended by trypsin. Solid line: enriched SPG (loose cells), after two rounds of depletion of adherent cells from duplicate 3-day culture. Both cell populations were prepared for FACS analysis of VASA expression as described in Materials and methods section. (D) Co-enrichment of SPG specific transcripts with the 'loose' cell population. Candidate SPG-enriched transcripts were amplified by RT-PCR from ACTB-normalized cDNAs extracted at 3 days of culture from total testis cells, enriched SPG (loose cells), and remaining adherent cells. ACTB RT-PCR was included as an internal control. Each panel of three lanes represents three RT-PCRs of three separate cell preparations derived from the same set of three donor testis cell suspensions. Lane (a) is from a 16-week-old Black Lab. Lanes (b and c) are from 10-week-old German Sheppard littermates. Primers are listed in Supplementary Table 3. Bars $=50 \mu \mathrm{m}$.
PLZF, cRet, Piwi1 (Lee et al. 2006), VASA, POUF5, NCAM (Li et al. 1998, Kubota et al. 2004), telomerase (TERT; Riou et al. 2005), and NANOS2 and 3 (Suzuki et al. 2009) were enriched in the 'loose cell' prep and depleted from the residual adherent cells, compared with total testis cells. These data strongly support the hypothesis that the 'loose cells' were canine SSC. Putative SPG marker RNAs, GFRA1, GPR125, ITGA6, and ITGB1, did not enrich with the canine SPGs, consistent with the lack of SPG-specific localization of the respective antigens by immunohistochemistry in canine testis (above). In addition UCHL1 mRNA was not enriched in the SPG pool, consistent with a posttranscriptional regulation in germ cells, or perhaps upregulation of the gene in cultured adherent cells as reported previously (Luo et al. 2006).

\section{Gene transfer into canine SPG}

To test the efficiency of gene transfer by lentivirus, freshly enriched SPG were transduced with lentiviral vectors containing either an EF1-GFP or a CMV-mCherry reporter and analyzed by flow cytometry for reporter expression. When cells were transduced with both vectors, at a multiplicity of infection (MOI) of five each and analyzed at $48 \mathrm{~h}$ (Fig. 5A and B) about 32\% of the cells expressed at least one reporter and $22 \%$ expressed both. As fibroblasts tend to rapidly out-grow the SPG in these cultures, a second experiment focused on reporter expression within the VASA + population. Cells were transduced at an MOI of 20 with the EF1-GFP reporter vector, then fixed, permeabilized, and labeled with the VASA antibody at $96 \mathrm{~h}$ for flow cytometry (Fig. 5C). The SPG population (retaining VASA expression) showed a transduction efficiency of 8.8\% under the conditions used here, based on GFP expression. Thus, it is possible to insert and express transgenes in these cells by standard lentiviral transduction at a significant level. Our data might underestimate the true transduction efficiency of SPG if a portion of the cells left the VASA + pool (differentiated or died) during the incubation period. 

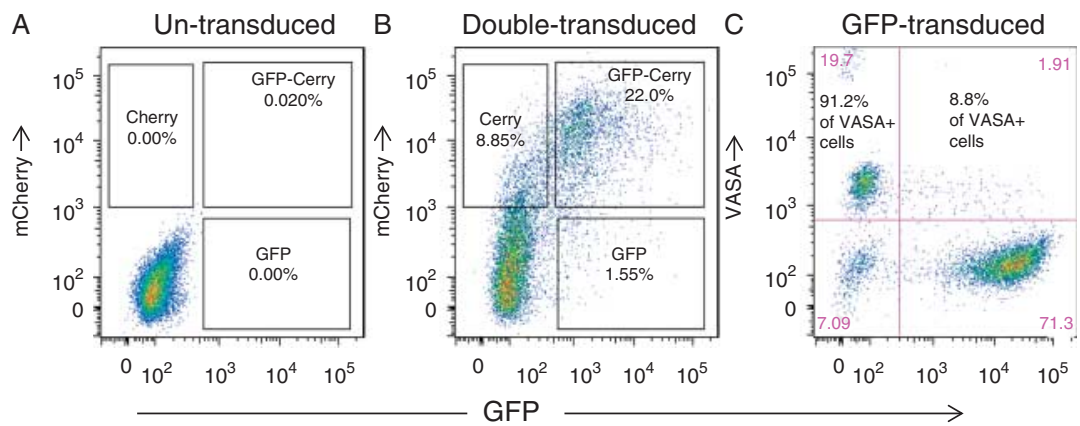

Figure 5 Gene transfer and expression in SPG by lentiviral transduction. (A and B) Co-transduction with EF1-GFP and CMV-mCherry at an MOI of 5 each. (A) FLOW diagram showing untreated control cells. (B) Same FLOW parameters showing expression of both vectors 4 days after a 15-h transduction. (C) Expression of EFI-GFP in VASA-positive cells. Freshly isolated SPGs were transduced at an MOI of 20 for $15 \mathrm{~h}$ and cultured for 4 days. Cells were fixed, permeabilized, probed for VASA using an Alexa-594 secondary antibody conjugate, and analyzed by FLOW cytometry. Two-dimensional dot plot of VASA and GFP gated on total live cells. Large print indicates percent distribution of GFP-expressing cells within VASA+ population.

\section{Behavior of canine SPG in culture}

Conditions for in vitro survival and expansion of rodent SSC have been extensively studied, suggesting appropriate conditions to try for canine SPG culture. The essential factor for self-renewal-type expansion of rodent SSC in culture is glial cell-derived neurotrophic factor (GDNF; Oatley et al. 2006). However, EGF and $\beta F G F$ and LIF enhance the proliferative effect of GDNF (Kanatsu-Shinohara et al. 2003). The inositol phosphateanchored GDNF co-receptor, GFR $\alpha 1$, which can be added effectively as a soluble agent, is essential in some strains of mice, suggesting that it is a limiting factor in those strains (Kubota et al. 2004). Additional signaling factors, including BDNF (Pyle et al. 2006), FGF9 (DiNapoli et al. 2006), NT3 (Pyle et al. 2006), NT4 (Pyle et al. 2006), pleiotropin (Soh et al. 2007), and Wnt3a (Golestaneh et al. 2009a), have been implicated as having facilitating roles in survival and/or selfrenewal, either in SSC directly or in the closely related ESC. Both serum levels and feeder cells have had mixed effects on SSC survival in the literature (Hamra et al. 2005). Matrix components, particularly laminin and collagen, are predicted to affect morphology, mobility, and regulation of SSC, based on the localization of these materials at the SSC niche, high levels of B1 and A6 integrins on SSCs, and an affinity for laminin (Shinohara et al. 1999).

In an attempt to establish an optimal culture environment for canine SSC, the enriched cells were cultured under a variety of conditions (Supplementary Table 1, see section on supplementary data given at the end of this article). Base conditions were either a serumfree medium (SG), optimized for murine SSC culture (Wu et al. 2009b), or DMEM/F12 with 10\% fetal bovine serum (FBS). Additional variables included feeder cells (canine, murine, and none), substratum (laminin, gelatin, and none), altered serum content $(10,1 \%$, and none), and a variety of growth factors implicated in the mouse literature as promoters of SSC self-renewal. As an initial criterion for successful SPG culture, we recorded presence or absence of VASA-positive cells after 1 month in culture. As seen in Supplementary Table 1, all culture conditions that included the established required components for rodent SSC self-renewal (SG medium with GDNF, FGF2, EGF, soluble GFRA1, and LIF; Wu et al. 2009b) maintained significant numbers of VASA-positive cells for at least a month (e.g. Fig. 6E). The individual components of this cocktail were not tested separately. Addition of feeder cells, matrix, or any of the other signaling molecules did not noticeably alter the number, staining intensity, morphology, or association of VASA-positive cells, as determined by microscopic observation over a 1 -month period. Therefore, all subsequent studies used culture condition $\# 12$ (SG medium with GDNF, FGF2, EGF, soluble GFRA1, LIF, and a laminin substratum).

In early cultures, most of the cells adhered to substratum but maintained a relatively rounded morphology compared with the elongated fibroblastlike cells in the culture (Fig. 6A and B). The rounded cells were often arrayed as connected chains, reminiscent of the syncytial chains of type A-aligned SPG in vivo (Hermann et al. 2009). By 8 days, fibroblasts had proliferated to form a confluent layer, and the lessadherent SPG-derived cells had formed irregular flattened clumps on top of the fibroblasts (Fig. 6C). These clumps retain VASA expression for many weeks, as shown in Fig. 6D and $E$, and remain distinct from the rapidly expanding somatic cell population (Supplementary Figure 2, see section on supplementary data given at the end of this article). Similar clumps of cells with similar morphology expressed several SPG markers in culture, including DAZL, UCHL1, and AP180 as well as VASA, all localized to similar clumps of cells with similar rounded morphology and round nuclei (Fig. 6F, $\mathrm{G}, \mathrm{H}$ and $\mathrm{I}$ ). The level of expression of a given marker varied significantly among members of the same clump (Fig. 6D), and the relative expression of different SPG 

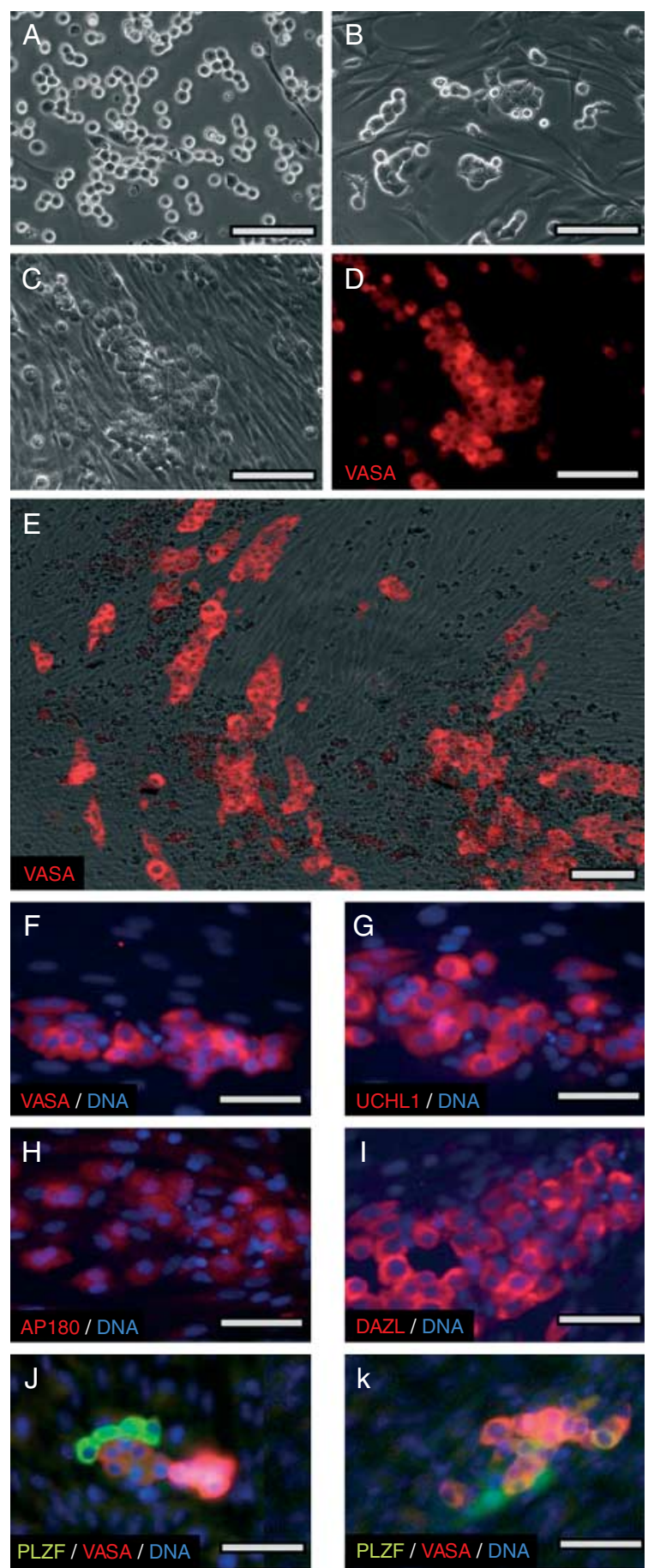

Figure 6 Behavior of canine SPG in culture. Enriched SPG from a 4-month-old black laboratory were cultured under condition \#12 (Supplementary Table 2). (A, B and C) Phase images of SPG on days 1, 3 , and 8 of culture respectively. (D) Fluorescent image of same field as (C) probed for VASA. (E) Low-power composite phase/fluorescence image of culture at 30 days showing clusters of tightly associated VASA-positive cells arranged on top of a confluent layer of fibroblastlike cells. (F, G, H and I) Localization of VASA (F), UCHL1 (G), AP180 $(\mathrm{H})$, and DAZL (I) at 2 weeks. ( $\mathrm{J}$ and $\mathrm{K}$ ) Co-localization of PLZF (green) and VASA (red) within SPG clusters. Nuclei in (F, G, H, I, J and K) are counterstained (blue) with Hoechst 33342. Bars $=50 \mu \mathrm{m}$ (A, B, C, D and E) or $25 \mu \mathrm{M}(\mathrm{F}, \mathrm{G}, \mathrm{H}, \mathrm{I}, \mathrm{J}$ and $\mathrm{K})$. markers varied among closely associated cells in the clumps (Fig. 6J and K). This might reflect varying stages of spermatogonial differentiation, as is the case in mature testis (see Fig. 2E). In fact, over 2 weeks of culture, cells expressing DAZL, UCHL1, or AP180 became relatively rare, while VASA-positive cells remained numerous (data not shown). The germ-line-specific mRNA expression profiles seen at the time of isolation was lost by 30 days (Supplementary Figure 3), consistent with the rapid expansion of somatic cells, and the probable loss of SPG over this period.

Although the marker-positive canine cells persisted for extended periods in culture, we have not yet been able to establish proliferating (non-differentiating) lines using available human and mouse growth factors. In one experiment, a set of replicate plates from a single SPG preparation was cultured without passage for 30 days. Plates were fixed and stained for VASA at intervals and the VASA + cells manually counted. There was no detectable loss or expansion of VASA + cells over this experiment. So far, any attempt to passage SPG clumps or entire populations leads to rapid loss of expression of the SPG markers.

\section{Transplantation of genetically manipulated SPG and production of transgenic sperm}

The only rigorous way to verify that the isolated 'loose' cells were SSC and that these cells retained true SSC characteristics after genetic manipulation is to demonstrate engraftment and donor spermatogenesis after transplantation into a host testis. To this end, six separate SPG preparations were transplanted into six recipient testes of three hounds. Four of the transplants used cells that had been previously transduced with a retroviral reporter (see Supplementary Table 4, see section on supplementary data given at the end of this article). Recipient hounds were prepared by focal irradiation of the testes, and $2-5 \times 10^{5}$ SPG were injected into the seminiferous tubules of each testis via retrograde injection into the rete testis. Owing to the low recovery of spermatogenesis, and complete lack of libido observed in previous transplants (Kim et al. 2008), the irradiation dose in this study was reduced from 3 days of 3 Gy/day to a single dose of 3 Gy.

Post-procedure, the recipient dogs showed normal sexual maturation, including normal-sized testes, normal libido, and interest in female urine. They also trained easily for manual ejaculation, allowing for periodic collections of sperm. Upon castration at 14 months post-transplant, the testis histology showed normal spermatogenic activity throughout the seminiferous tissue (Supplementary Figure 4). Epidydimal sperm content, determined at the time of castration, was in the normal range, varying from $1.1-4.6 \times 10^{8}$ cells in the two dogs that received transgenic SPG (Supplementary Table 4). 

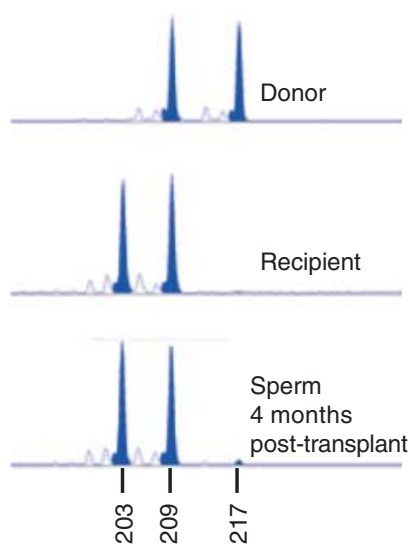

B

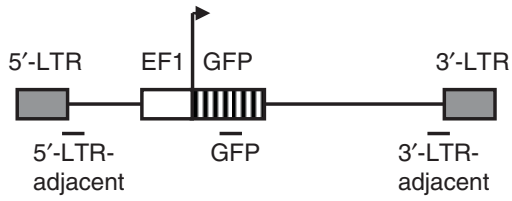

C

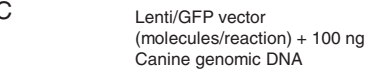

Sperm DNA
$(100 \mathrm{ng} / \mathrm{reac}$ )

(40000 cells)

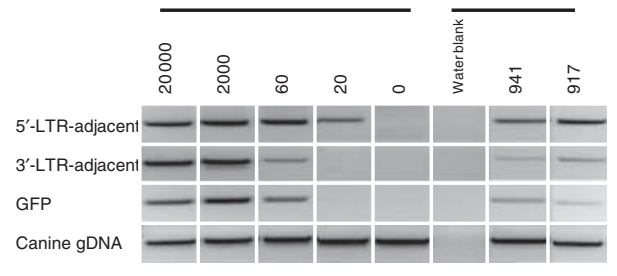

Figure 7 Engraftment of transgenic SSC. (A) At 4 months post-transplant, a sperm sample from recipient 795933 was tested for donor sperm contribution by VNTR. Microsatellite FM2611 was amplified from donor (A) and recipient (B) DNA as well as from post-transplant sperm. The donorspecific allele (217 bp product) was also evident in the sperm DNA sample at a level of about $1 \%$, as calculated by comparison of the areas under the donor- and recipient-specific (203 bp) peaks. (B) Diagram of EF1-GFP vector, showing three regions amplified for corroborated detection of vector. (C) PCR of EF1-GFP vector from ejaculated sperm of two transplanted dogs. Sperm was taken 14 months after each dog (941 and 917) had been transplanted with SPG that had been transduced with the EF1-GFP virus. Sperm DNA (100 ng), representing 40 000 haploid cells, were analyzed in three separate PCR representing three regions of the vector. Control reactions contained 100 ng normal dog DNA plus a tittered number of copies of the vector. A fourth PCR of the canine Myc gene served as an internal control for genomic DNA. Primers are listed in Supplementary Table 3.

Sperm samples were analyzed for donor DNA contribution at 4 months by variable number tandem repeat (VNTR). In replicate reactions, each animal showed donor signals at or near the threshold of detection ( $1 \%$ donor) by VNTR assay (e.g. Fig. $7 \mathrm{~A})$. Standard curves for donor chimerism indicated no reliable quantitative information below $1 \%$ due to random noise. Similar equivocal VNTR evidence for donor sperm was obtained through 15 months posttransplant (data not shown). Thus, donor contribution in these dogs remained at or below $1 \%$ and could not be accurately quantified by this method.

As a more sensitive alternative assay, sperm DNA was analyzed for the presence of the reporter vector, PL-SINEF1a-EGFP, by PCR in the two animals that received transgenic SPGs. As shown in Fig. 7B, three separate PCR, amplifying three regions of the vector, were performed in parallel for internal verification. Both dogs yielded vector-positive sperm (Fig. 7C) by this assay, while sperm from the non-transduced dog was negative. Based on the included vector standards, the copy number was between 20 and 60 copies/40 000 haploid cells. If we assume a vector copy number of 40/ 40000 cells, an SPG transduction efficiency of $9 \%$ (shown above) and a vector copy/cell value of 1 (predicted from the low transduction efficiency), then we can estimate that about $0.1 \%$ of the total sperm were transgenic and that about $1.0 \%$ were of donor origin. This calculated figure was consistent with our VNTR results, showing positive signals at the $1 \%$ detection threshold.

\section{Discussion}

Our long-term goal is to develop a robust strategy for generating transgenic canine models. Traditional approaches to transgenics have focused on introducing transgenes either directly into oocytes and zygotes or indirectly into early embryos via replacement of inner cell mass cells with ESC or cloned cell. These approaches require the ability to harvest significant numbers of oocytes or embryos from the female reproductive tract, manipulate them in vitro without damage, and implant them efficiently into a surrogate mother. The difficulties in performing these tasks, the low yields and high costs of traditional cloning, and the absence of clear cut, genetically stable ESCs in most species combined to make development of transgenesis in large animal models a very expensive and time-consuming endeavor. The development of SSC transplantation in rodents, as an alternative to embryomediated gene transfer, opened a new opportunity to explore this relatively less invasive, more efficient and lower cost approach in canines and other larger animal models. Successful SSC transplantations in several large animals (Izadyar et al. 2003, Kim et al. 2008, Herrid et al. 2011, Jahnukainen et al. 2011, Hermann et al. 2012, Zeng et al. 2012) led us believe this approach could be applied to the dog model.

Previously, we demonstrated that canine SSC can be transplanted successfully, that they can reestablish regions of normal spermatogenesis, and that they can generate mature donor-derived sperm in a host testis 
(Kim et al. 2008). In that study, unfractionated seminiferous tubule cells were transplanted to a donor testis without enrichment, culture, or genetic manipulation. In order to exploit SSC transplantation as a viable approach to canine transgenesis, the efficiencies of SSC collection, gene transfer, engraftment, and donor sperm production will have to be optimized. Ideally, this may require clonal expansion of lines of transgenic SSC to achieve sufficient cell numbers and genetic homogeneity to guarantee a high level of transgenic sperm production and thus a practical ratio of transgenic to wild-type offspring. Here, we extended the previous findings by developing and assessing methods to isolate, culture, and genetically manipulate canine SPG. We then tested whether or not engraftment potential is maintained after these manipulations.

Based on the rich data available on SPG markers in rodents and other animals, we were able to identify similar antigens and mRNAs that uniquely identified SPG and their progeny in canine testis. Several of these markers, including VASA, PLZF, DAZL, UCHLI, and AP180, were detectable, using commercially available antibodies, in prepubertal gonocytes, adult SPG, and cultured SPG. These antibodies facilitated tracking SPG through isolation and culture. Interestingly, five cell surface molecules (GFRA1, GPR125, ITGA6, ITGB1, and $\alpha$-D- $N$-acetyl-galactosamine), which have been useful for flow cytometry-based enrichment of SPG from other species, were either undetectable or nonspecific for canine SPG. In the absence of a useful surface marker, we exploited a differential matrix affinity method for enrichment of canine SPG from prepubertal testis to $70 \%$ purity. The identity of this population was confirmed by the co-enrichment of mRNAs for 11 wellestablished SPG-specific genes. Lentiviral transduction of the enriched SPG yielded about 9\% reporter-positive cells. Thus, it is now possible to prepare and cryopreserve a population of $0.5-1 \times 10^{6} 70 \%$ pure canine SPG with $9 \%$ lentiviral marking from an average-sized prepubertal dog.

When cultured under the optimal conditions established for mice, the enriched canine SPG persisted as VASA + cells for several weeks. Under these conditions, some cells remain positive for several markers of SPG, including VASA, DAZL, UCHL1, AP180, and PLZF, suggesting that they may retain their SSC phenotype in culture. However, most of the VASA-positive cells lost expression of other primitive markers, suggesting loss of the SSC phenotype. Furthermore, there was no evidence of expansion of germ-line cells. The standard methods used by mouse SSC investigators of serially passaging clumps of rounded cells led to loss of SPG markers, as did trypsin-mediated or manual passage of the cells. Extensive testing of culture conditions did not reveal any advantage conferred by addition of feeder cells, matrix components, or other growth factors reported to enhance self-renewal divisions of mouse SSC. Thus, while canine SPG can be maintained in culture for weeks, conditions for expansion remain to be established. For the most part, these results parallel those reported from other large animal spermatogonial cell cultures. Short-term expansions of germ-line cells with SPG markers reported for human (He et al. 2010), pig (Kuijk et al. 2009), and bovine (Aponte et al. 2008) suggest that large animal SSC lines may soon be possible. However, in no case, has a stable line of SSC been reported from a large animal.

We have demonstrated, for the first time in dogs, that transplantation of transgenic SPG can lead to engraftment in a host testis and transmit the transgene to mature spermatozoa. This extends the findings in our previous study (Kim et al. 2008), establishing engraftment of unfractionated, un-manipulated canine testis cells. In addition to the changes in donor cell manipulation, this study significantly changed the preconditioning regimen for host testes. In the first study, a fractionated dose of 9 Gy, 8 weeks before transplantation was used to eliminate endogenous stem cells. While this regimen was consistent with those used successfully in other large animals (Kim et al. 2006, Herrid et al. 2009, Jahnukainen et al. 2011, Zeng et al. 2012), it may have delivered too high a dose for the dog, as testis size, sperm count, and libido did not recover and sperm had to be recovered from the epididymis. Therefore, we reduced the irradiation dose to $3 \mathrm{~Gy}$ in this study. The lower radiation dose used resulted in complete recovery of libido, testis size, spermatogenesis, and sperm count. However, most of the recovery was undoubtedly from endogenous SSC that escaped the preconditioning, possibly inhibiting donor engraftment. The typical interval of several weeks between irradiation and transplant is based on the logic that tissue damage and inflammation caused by irradiation will interfere with homing of stem cells to their niche (Herrid et al. 2011). However, there is not a compelling body of empirical data to confirm this. Arguably, disruption of the tissue might actually facilitate entry of the SSC to their niche by disturbing the Sertoli cell tight junctions that block entry to that niche (Takashima et al. 2011). Hematopoietic stem cell homing to bone marrow is actually enhanced, not blocked, by local irradiation 24-h before infusion of the cells (Bastianutto et al. 2007). Thus, we used a single dose of $3 \mathrm{~Gy}$, immediately before transplant. The optimal preconditioning regimen probably lies between those of our two studies.

By our calculation, the enriched and genetically modified SSC used here engrafted almost as well as did the un-enriched, untreated canine cells of our previous study. Based on histology, only a $5-15 \%$ recovery of spermatogenesis was observed in the first study, after 9 Gy of total irradiation. This was supported by about a $10 \%$ of normal sperm count. Thus, the observed $20 \%$ donor sperm represented about $2 \%$ of normal sperm production. In contrast, after a 3 Gy dose in this study, 
both histology and sperm count were normal, indicating a $100 \%$ recovery of spermatogenesis. Thus, the $1 \%$ donor sperm generated in these animals represented $1 \%$ of normal total germ cell activity and sperm production. As a large fraction of endogenous SSC survived the present 3 Gy preconditioning, it is also likely that these cells inhibited homing and engraftment of donor cells, either by physical exclusion or by homeostatic signaling mechanisms that regulate self-renewal (Caires et al. 2010, 2012). From this comparison, we conclude that the level of donor engraftment in these two studies was similar, in spite of differences in preconditioning of the recipient tissue or isolation and manipulation of the donor cells. Similar studies with other large animals have yielded variable levels of donor sperm production (Honaramooz et al. 2003, Izadyar et al. 2003, Herrid et al. 2009, 2011, Jahnukainen et al. 2011, Hermann et al. 2012, Zeng et al. 2012, 2013), ranging from $<1 \%$ to as high as $30 \%$ in sheep (Herrid et al. 2009).

The relatively low donor sperm levels observed here must be improved before canine SSC transplantation can be exploited as a practical approach for transgenesis. Optimization of the preconditioning regimen may yield a large improvement. Another area worthy of improvement may be immune compatibility. In this study, no attempt was made to match host and donor. The blood-testis barrier, which protects developing germ cells in the tubule lumen from immune surveillance, may not fully protect SSC. These cells reside outside the barrier formed by Sertoli cell tight junctions. However, there is also some degree of immune privilege outside the barrier, as immunologically unmatched SSC transplants in bull (Izadyar et al. 2003), goat (Honaramooz et al. 2003), pig (Mikkola et al. 2006), as well as dog (Kim et al. 2008) have led to engraftment. Of note, unrelated SSC transplants in bulls yield significantly lower levels of engraftment than autologous transplants (Izadyar et al. 2003), suggesting that work on this point might help improve efficiency. The importance of donor/ host interactions for canine SSC transplants remains to be determined.

Finally, establishment of culture conditions for true clonal expansion of canine SSC, such as is routine in mice, will also be extremely useful. A uniform clone of transgenic SSC would yield a greater than tenfold increase in the percent of transgenic cells over a primary transduction efficiency of $9 \%$. It would also facilitate unlimited expansion, a 100-fold increase in the number of total SSC injected, would not exceed the cell numbers injected in our first study. It would also facilitate selection confirmation and expansion of low-frequency events, such as homologous recombination, before transplantation. All these factors will greatly affect the level of transgenic sperm production, and hence, the efficiency of generating transgenic offspring. A major obstacle to expansion of canine SSC may be speciesspecific qualities of self-renewal regulation. First, the available non-canine growth factors used in this study may not be fully compatible with the canine receptors. Secondly, canine SSC may utilize one or more alternative signaling pathways not observed in mice. With these caveats in mind, we are presently exploring both the production of canine growth factors, particularly GDNF, and genetic manipulation of canine SSC to bypass the requirement for GDNF (Lee et al. 2007, 2009).

\section{Supplementary data}

This is linked to the online version of the paper at http://dx.doi. org/10.1530/REP-13-0086.

\section{Declaration of interest}

The authors declare that there is no conflict of interest that could be perceived as prejudicing the impartiality of the research reported.

\section{Funding}

This work was supported in part by Pilot grant 20003812 from the Northwest Genome Engineering Consortium (NIH grant 1-UL1-RR024921-01) and by NIH Challenge grant: NHBLI-1-RC1-HL100270-01.

\section{Acknowledgements}

The authors acknowledge the services of the Core Center of Excellence in Hematology (funded by NIH grant 3P30DK056465-11S2) for provision of canine mRNAs and reporter constructs, as well as design of RT-PCR primers and isolation of DNA and RNA samples. The authors thank Dr Margaret McEntee and her staff at the Jane M Turrel Radiation Therapy Suite at Cornell's College of Veterinary Medicine for their generous assistance with recipient preparation. They also thank Deborah Higginbotham, Gretchen Johnson, Emily Meyer, and Darlene John for technical assistance. They also thank Bonnie Larson and Helen Crawford for assistance with the preparation and editing of the manuscript.

\section{References}

Acland GM, Aguirre GD, Bennett J, Aleman TS, Cideciyan AV, Bennicelli J, Dejneka NS, Pearce-Kelling SE, Maguire AM, Palczewski K et al. 2005 Long-term restoration of rod and cone vision by single dose rAAV-mediated gene transfer to the retina in a canine model of childhood blindness. Molecular Therapy 12 1072-1082. (doi:10.1016/j.ymthe. 2005.08.008)

An LY, Yuan YG, Yu BL, Yang TJ \& Cheng Y 2012 Generation of human lactoferrin transgenic cloned goats using donor cells with dual markers and a modified selection procedure. Theriogenology 78 1303-1311. (doi:10.1016/j.theriogenology.2012.05.027)

Anderson RA, Fulton N, Cowan G, Coutts S \& Saunders PT 2007 Conserved and divergent patterns of expression of DAZL, VASA and OCT4 in the germ cells of the human fetal ovary and testis. BMC Developmental Biology 7 136. (doi:10.1186/1471-213X-7-136) 
Aponte PM, Soda T, Teerds KJ, Mizrak SC, van de Kant HJ \& de Rooij DG 2008 Propagation of bovine spermatogonial stem cells in vitro. Reproduction 136 543-557. (doi:10.1530/REP-07-0419)

Athanasiou KA, Agarwal A, Muffoletto A, Dzida FJ, Constantinides G \& Clem M 1995 Biomechanical properties of hip cartilage in experimental animal models. Clinical Orthopaedics and Related Research 254-266.

Bastianutto C, Mian A, Symes J, Mocanu J, Alajez N, Sleep G, Shi W, Keating A, Crump M, Gospodarowicz M et al. 2007 Local radiotherapy induces homing of hematopoietic stem cells to the irradiated bone marrow. Cancer Research 67 10112-10116. (doi:10.1158/0008-5472. CAN-07-2192)

Bjarnadottir TK, Fredriksson R, Hoglund PJ, Gloriam DE, Lagerstrom MC \& Schioth HB 2004 The human and mouse repertoire of the adhesion family of G-protein-coupled receptors. Genomics 84 23-33. (doi:10.1016/j.ygeno.2003.12.004)

Caires K, Broady J \& McLean D 2010 Maintaining the male germline: regulation of spermatogonial stem cells. Journal of Endocrinology 205 133-145. (doi:10.1677/JOE-09-0275)

Caires KC, de Avila JM, Cupp AS \& McLean DJ 2012 VEGFA family isoforms regulate spermatogonial stem cell homeostasis in vivo. Endocrinology 153 887-900. (doi:10.1210/en.2011-1323)

Castrillon DH, Quade BJ, Wang TY, Quigley C \& Crum CP 2000 The human VASA gene is specifically expressed in the germ cell lineage. PNAS $\mathbf{9 7}$ 9585-9590. (doi:10.1073/pnas.160274797)

Conrad S, Renninger $M$, Hennenlotter J, Wiesner T, Just $L$, Bonin $M$, Aicher W, Buhring HJ, Mattheus U, Mack A et al. 2008 Generation of pluripotent stem cells from adult human testis. Nature 456 344-349. (doi:10.1038/nature07404)

DiNapoli L, Batchvarov J \& Capel B 2006 FGF9 promotes survival of germ cells in the fetal testis. Development 133 1519-1527. (doi:10.1242/dev. 02303)

Gerwe BA, Angel PM, West FD, Hasneen K, Young A, Orlando R \& Stice SL 2011 Membrane proteomic signatures of karyotypically normal and abnormal human embryonic stem cell lines and derivatives. Proteomics 11 2515-2527. (doi:10.1002/pmic.201000032)

Giraldo AM, Ball S \& Bondioli KR 2012 Production of transgenic and knockout pigs by somatic cell nuclear transfer. Methods in Molecular Biology 885 105-123.

Goel S, Sugimoto M, Minami N, Yamada M, Kume S \& Imai H 2007 Identification, isolation, and in vitro culture of porcine gonocytes. Biology of Reproduction 77 127-137. (doi:10.1095/biolreprod.106. 056879)

Golestaneh N, Beauchamp E, Fallen S, Kokkinaki M, Uren A \& Dym M 2009a Wnt signaling promotes proliferation and stemness regulation of spermatogonial stem/progenitor cells. Reproduction 138 151-162. (doi:10.1530/REP-08-0510)

Golestaneh N, Kokkinaki M, Pant D, Jiang J, DeStefano D, Fernandez-Bueno C, Rone JD, Haddad BR, Gallicano GI \& Dym M $2009 \mathrm{~b}$ Pluripotent stem cells derived from adult human testes. Stem Cells and Development 18 1115-1126. (doi:10.1089/scd.2008.0347)

Gordon IK \& Khanna C 2010 Modeling opportunities in comparative oncology for drug development. ILAR Journal 51 214-220. (doi:10.1093/ ilar.51.3.214)

Graves SS, Hogan W, Kuhr CS, Diaconescu R, Harkey MA, Georges GE, Sale GE, Zellmer E, Baran SW, Jochum C et al. 2007 Stable trichimerism after marrow grafting from 2 DLA-identical canine donors and nonmyeloablative conditioning. Blood 110 418-423. (doi:10.1182/ blood-2007-02-071282)

Grisanti L, Falciatori I, Grasso M, Dovere L, Fera S, Muciaccia B, Fuso A, Berno V, Boitani C, Stefanini M et al. 2009 Identification of spermatogonial stem cell subsets by morphological analysis and prospective isolation. Stem Cells 27 3043-3052. (doi:10.1002/stem.206)

Guan K, Nayernia K, Maier LS, Wagner S, Dressel R, Lee JH, Nolte J, Wolf F, Li M, Engel W et al. 2006 Pluripotency of spermatogonial stem cells from adult mouse testis. Nature 440 1199-1203. (doi:10.1038/ nature04697)

Hamra FK, Chapman KM, Nguyen DM, Williams-Stephens AA, Hammer RE \& Garbers DL 2005 Self renewal, expansion, and transfection of rat spermatogonial stem cells in culture. PNAS 102 17430-17435. (doi:10.1073/pnas.0508780102)
Hamra FK, Chapman KM, Wu Z \& Garbers DL 2008 Isolating highly pure rat spermatogonial stem cells in culture. Methods in Molecular Biology 450 163-179.

Hayes B, Fagerlie SR, Ramakrishnan A, Baran S, Harkey M, Graf L, Bar M, Bendoraite A, Tewari M \& Torok-Storb B 2008 Derivation, characterization, and in vitro differentiation of canine embryonic stem cells. Stem Cells 26 465-473. (doi:10.1634/stemcells.2007-0640)

He Z, Kokkinaki M, Jiang J, Dobrinski I \& Dym M 2010 Isolation, characterization, and culture of human spermatogonia. Biology of Reproduction 82 363-372. (doi:10.1095/biolreprod.109.078550)

Hermann BP, Sukhwani M, Lin CC, Sheng Y, Tomko J, Rodriguez M, Shuttleworth JJ, McFarland D, Hobbs RM, Pandolfi PP et al. 2007 Characterization, cryopreservation, and ablation of spermatogonial stem cells in adult rhesus macaques. Stem Cells 25 2330-2338. (doi:10.1634/ stemcells.2007-0143)

Hermann BP, Sukhwani M, Simorangkir DR, Chu T, Plant TM \& Orwig KE 2009 Molecular dissection of the male germ cell lineage identifies putative spermatogonial stem cells in rhesus macaques. Human Reproduction 24 1704-1716. (doi:10.1093/humrep/dep073)

Hermann BP, Sukhwani M, Winkler F, Pascarella JN, Peters KA, Sheng Y, Valli H, Rodriguez M, Ezzelarab M, Dargo G et al. 2012 Spermatogonial stem cell transplantation into rhesus testes regenerates spermatogenesis producing functional sperm. Cell Stem Cell 11 715-726. (doi:10.1016/j. stem.2012.07.017)

Herrid M, Olejnik J, Jackson M, Suchowerska N, Stockwell S, Davey R, Hutton K, Hope S \& Hill JR 2009 Irradiation enhances the efficiency of testicular germ cell transplantation in sheep. Biology of Reproduction $\mathbf{8 1}$ 898-905. (doi:10.1095/biolreprod.109.078279)

Herrid M, Davey R, Stockwell S, Olejnik J, Schmoelzl S, Suchowerska N, Jackson M, Holland M \& Hill JR 2011 A shorter interval between irradiation of recipient testis and germ cell transplantation is detrimental to recovery of fertility in rams. International Journal of Andrology $\mathbf{3 4}$ 501-512. (doi:10.1111/j.1365-2605.2010.01113.x)

Hilgendorf I, Weirich V, Zeng L, Koppitz E, Wegener R, Freund \& Junghanss C 2005 Canine haematopoietic chimerism analyses by semiquantitative fluorescence detection of variable number of tandem repeat polymorphism. Veterinary Research Communications 29 103-110. (doi:10.1023/B:VERC.0000047486.01458.c5)

Honaramooz A, Behboodi E, Megee SO, Overton SA, Galantino-Homer H, Echelard Y \& Dobrinski I 2003 Fertility and germline transmission of donor haplotype following germ cell transplantation in immunocompetent goats. Biology of Reproduction 69 1260-1264. (doi:10.1095/ biolreprod.103.018788)

Hong SG, Kim MK, Jang G, Oh HJ, Park JE, Kang JT, Koo OJ, Kim T, Kwon MS, Koo BC et al. 2009 Generation of red fluorescent protein transgenic dogs. Genesis 47 314-322. (doi:10.1002/dvg.20504)

Hong SG, Oh HJ, Park JE, Kim MJ, Kim GA, Park EJ, Koo OJ, Kang SK, Jang G \& Lee BC 2011 Production of offspring from cloned transgenic RFP female dogs and stable generational transmission of the RFP gene. Genesis 49 835-840. (doi:10.1002/dvg.20772)

Hotta A, Cheung AY, Farra N, Vijayaragavan K, Seguin CA, Draper JS, Pasceri P, Maksakova IA, Mager DL, Rossant J et al. 2009 Isolation of human iPS cells using EOS lentiviral vectors to select for pluripotency. Nature Methods 6 370-376. (doi:10.1038/nmeth.1325)

Izadyar F, Spierenberg GT, Creemers LB, den Ouden K \& de Rooij DG 2002 Isolation and purification of type A spermatogonia from the bovine testis. Reproduction 124 85-94. (doi:10.1530/rep.0.1240085)

Izadyar F, Den Ouden K, Stout TA, Stout J, Coret J, Lankveld DP, Spoormakers TJ, Colenbrander B, Oldenbroek JK, Van der Ploeg KD et al. 2003 Autologous and homologous transplantation of bovine spermatogonial stem cells. Reproduction 126 765-774. (doi:10.1530/ rep.0.1260765)

Izadyar F, Pau F, Marh J, Slepko N, Wang T, Gonzalez R, Ramos T, Howerton K, Sayre C \& Silva F 2008 Generation of multipotent cell lines from a distinct population of male germ line stem cells. Reproduction 135 771-784. (doi:10.1530/REP-07-0479)

Jahnukainen K, Ehmcke J, Quader MA, Saiful Huq M, Epperly MW, Hergenrother S, Nurmio M \& Schlatt S 2011 Testicular recovery after irradiation differs in prepubertal and pubertal non-human primates, and can be enhanced by autologous germ cell transplantation. Human Reproduction 26 1945-1954. (doi:10.1093/humrep/der160) 
Jijiwa M, Kawai K, Fukihara J, Nakamura A, Hasegawa M, Suzuki C, Sato T, Enomoto A, Asai N, Murakumo Y et al. 2008 GDNF-mediated signaling via RET tyrosine 1062 is essential for maintenance of spermatogonial stem cells. Genes to Cells 13 365-374. (doi:10.1111/j.1365-2443.2008. 01171.x)

Jung EM, An BS, Kim YK, Hwang I, Lee JY, Shin TY, Hyun SH, Hwang WS \& Jeung EB 2013 Establishment of transgenic fibroblasts for producing recombinant human interferon- $\alpha$ and erythropoietin in bovine milk. Molecular Medicine Reports 7 406-412. (doi:10.3892/mmr.2012.1182)

Kanatsu-Shinohara M \& Shinohara T 2007 Culture and genetic modification of mouse germline stem cells. Annals of the New York Academy of Sciences 1120 59-71. (doi:10.1196/annals.1411.001)

Kanatsu-Shinohara M, Ogonuki N, Inoue K, Miki H, Ogura A, Toyokuni S \& Shinohara T 2003 Long-term proliferation in culture and germline transmission of mouse male germline stem cells. Biology of Reproduction 69 612-616. (doi:10.1095/biolreprod.103.017012)

Kanatsu-Shinohara M, Toyokuni S \& Shinohara T 2004 Transgenic mice produced by retroviral transduction of male germ line stem cells in vivo. Biology of Reproduction 71 1202-1207. (doi:10.1095/biolreprod.104. 031294)

Kanatsu-Shinohara M, Ogonuki N, Iwano T, Lee J, Kazuki Y, Inoue K, Miki H, Takehashi M, Toyokuni S, Shinkai Y et al. 2005 Genetic and epigenetic properties of mouse male germline stem cells during longterm culture. Development 132 4155-4163. (doi:10.1242/dev.02004)

Kanatsu-Shinohara M, Ikawa M, Takehashi M, Ogonuki N, Miki H, Inoue K, Kazuki Y, Lee J, Toyokuni S, Oshimura M et al. 2006 Production of knockout mice by random or targeted mutagenesis in spermatogonial stem cells. PNAS 103 8018-8023. (doi:10.1073/pnas.0601139103)

Kanatsu-Shinohara M, Kato-Itoh M, Ikawa M, Takehashi M, Sanbo M, Morioka Y, Tanaka T, Morimoto H, Hirabayashi M \& Shinohara T 2011 Homologous recombination in rat germline stem cells. Biology of Reproduction 85 208-217. (doi:10.1095/biolreprod.111.090837)

Ketola I, Anttonen M, Vaskivuo T, Tapanainen JS, Toppari J \& Heikinheimo M 2002 Developmental expression and spermatogenic stage specificity of transcription factors GATA- 1 and GATA- 4 and their cofactors FOG-1 and FOG-2 in the mouse testis. European Journal of Endocrinology 147 397-406. (doi:10.1530/eje.0.1470397)

Kim Y, Selvaraj V, Dobrinski I, Lee H, McEntee MC \& Travis AJ 2006 Recipient preparation and mixed germ cell isolation for spermatogonial stem cell transplantation in domestic cats. Journal of Andrology 27 248-256. (doi:10.2164/jandrol.05034)

Kim Y, Turner D, Nelson J, Dobrinski I, McEntee M \& Travis AJ 2008 Production of donor-derived sperm after spermatogonial stem cell transplantation in the dog. Reproduction 136 823-831. (doi:10.1530/ REP-08-0226)

Kim EY, Noh EJ, Park HY, Park MJ, Noh EH, Lee JB, Jeong CJ, Lee DS, Riu KZ \& Park SP 2012 Establishment of bovine embryonic stem cell lines using a minimized feeder cell drop. Cellular Reprogramming 14 520-529. (doi:10.1089/cell.2012.0038)

von Kopylow K, Kirchhoff C, Jezek D, Schulze W, Feig C, Primig M, Steinkraus V \& Spiess AN 2010 Screening for biomarkers of spermatogonia within the human testis: a whole genome approach. Human Reproduction 25 1104-1112. (doi:10.1093/humrep/deq053)

Kubota H, Avarbock MR \& Brinster RL 2004 Growth factors essential for self-renewal and expansion of mouse spermatogonial stem cells. PNAS 101 16489-16494. (doi:10.1073/pnas.0407063101)

Kuijk EW, Colenbrander B \& Roelen BA 2009 The effects of growth factors on in vitro-cultured porcine testicular cells. Reproduction 138 721-731. (doi:10.1530/REP-09-0138)

Kumar De A, Malakar D, Akshey YS, Jena MK \& Dutta R 2011 Isolation and characterization of embryonic stem cell-like cells from in vitro produced goat (Capra hircus) embryos. Animal Biotechnology 22 181-196. (doi:10.1080/10495398.2011.622189)

Lee JH, Schutte D, Wulf G, Fuzesi L, Radzun HJ, Schweyer S, Engel W \& Nayernia K 2006 Stem-cell protein Piwil2 is widely expressed in tumors and inhibits apoptosis through activation of Stat $3 / \mathrm{BCl}-\mathrm{XL}$ pathway. Human Molecular Genetics 15 201-211. (doi:10.1093/hmg/ddi430)

Lee J, Kanatsu-Shinohara M, Inoue K, Ogonuki N, Miki H, Toyokuni S, Kimura T, Nakano T, Ogura A \& Shinohara T 2007 Akt mediates selfrenewal division of mouse spermatogonial stem cells. Development 134 1853-1859. (doi:10.1242/dev.003004)
Lee J, Kanatsu-Shinohara $M$, Morimoto $H$, Kazuki $Y$, Takashima S, Oshimura M, Toyokuni S \& Shinohara T 2009 Genetic reconstruction of mouse spermatogonial stem cell self-renewal in vitro by Ras-cyclin D2 activation. Cell Stem Cell 5 76-86. (doi:10.1016/j.stem.2009.04.020)

Li LH, Jester WF Jr \& Orth JM 1998 Expression of 140-kDa neural cell adhesion molecule in developing testes in vivo and in long-term Sertoli cell-gonocyte cocultures. Journal of Andrology 19 365-373.

Lingaas F, Comstock KE, Kirkness EF, Sorensen A, Aarskaug T, Hitte C, Nickerson ML, Moe L, Schmidt LS, Thomas R et al. 2003 A mutation in the canine BHD gene is associated with hereditary multifocal renal cystadenocarcinoma and nodular dermatofibrosis in the German Shepherd dog. Human Molecular Genetics 12 3043-3053. (doi:10.1093/hmg/ddg336)

Luo J, Megee S, Rathi R \& Dobrinski I 2006 Protein gene product 9.5 is a spermatogonia-specific marker in the pig testis: application to enrichment and culture of porcine spermatogonia. Molecular Reproduction and Development 73 1531-1540. (doi:10.1002/mrd.20529)

Lupu M \& Storb R 2007 Five decades of progress in haematopoietic cell transplantation based on the preclinical canine model. Veterinary and Comparative Oncology 5 14-30. (doi:10.1111/j.1476-5829.2006. 00114.x)

McCoard SA, Lunstra DD, Wise TH \& Ford JJ 2001 Specific staining of Sertoli cell nuclei and evaluation of Sertoli cell number and proliferative activity in Meishan and White Composite boars during the neonatal period. Biology of Reproduction 64 689-695. (doi:10.1095/biolreprod64.2.689)

Mikkola M, Sironen A, Kopp C, Taponen J, Sukura A, Vilkki J, Katila T \& Andersson M 2006 Transplantation of normal boar testicular cells resulted in complete focal spermatogenesis in a boar affected by the immotile short-tail sperm defect. Reproduction in Domestic Animals $\mathbf{4 1}$ 124-128. (doi:10.1111/j.1439-0531.2006.00651.x)

Mizrak SC, Chikhovskaya JV, Sadri-Ardekani H, van Daalen S, Korver CM, Hovingh SE, Roepers-Gajadien HL, Raya A, Fluiter K, de Reijke TM et al. 2010 Embryonic stem cell-like cells derived from adult human testis. Human Reproduction 25 158-167. (doi:10.1093/humrep/dep354)

Nagano M, Ryu BY, Brinster CJ, Avarbock MR \& Brinster RL 2003 Maintenance of mouse male germ line stem cells in vitro. Biology of Reproduction 68 2207-2214. (doi:10.1095/biolreprod.102.014050)

Nayernia K, Li M \& Engel W 2004 Spermatogonial stem cells. Methods in Molecular Biology 253 105-120. (doi:10.1385/1-59259-744-0:105)

Noce T, Okamoto-Ito S \& Tsunekawa N 2001 Vasa homolog genes in mammalian germ cell development. Cell Structure and Function 26 131-136. (doi:10.1247/csf.26.131)

Nowend KL, Starr-Moss AN \& Murphy KE 2011 The function of dog models in developing gene therapy strategies for human health. Mammalian Genome 22 476-485. (doi:10.1007/s00335-011-9348-0)

Oatley JM \& Brinster RL 2006 Spermatogonial stem cells. Methods in Enzymology 419 259-282. (doi:10.1016/S0076-6879(06)19011-4)

Oatley JM \& Brinster RL 2008 Regulation of spermatogonial stem cell selfrenewal in mammals. Annual Review of Cell and Developmental Biology 24 263-286. (doi:10.1146/annurev.cellbio.24.110707.175355)

Oatley JM, Avarbock MR, Telaranta Al, Fearon DT \& Brinster RL 2006 Identifying genes important for spermatogonial stem cell self-renewal and survival. PNAS 103 9524-9529. (doi:10.1073/pnas.0603332103)

Oatley JM, Kaucher AV, Avarbock MR \& Brinster RL 2010 Regulation of mouse spermatogonial stem cell differentiation by STAT3 signaling. Biology of Reproduction 83 427-433. (doi:10.1095/biolreprod.109. 083352)

Okazuka K, Beard BC, Emery DW, Schwarzwaelder K, Spector MR, Sale GE, von Kalle C, Torok-Storb B, Kiem HP \& Blau CA 2011 Longterm regulation of genetically modified primary hematopoietic cells in dogs. Molecular Therapy 19 1287-1294. (doi:10.1038/mt.2011.8)

Pyle AD, Lock LF \& Donovan PJ 2006 Neurotrophins mediate human embryonic stem cell survival. Nature Biotechnology 24 344-350. (doi:10.1038/nbt1189)

Riou L, Bastos H, Lassalle B, Coureuil M, Testart J, Boussin FD, Allemand I \& Fouchet $\mathbf{P} 2005$ The telomerase activity of adult mouse testis resides in the spermatogonial $\alpha 6$-integrin-positive side population enriched in germinal stem cells. Endocrinology 146 3926-3932. (doi:10.1210/en. 2005-0502)

Rodriguez-Sosa JR, Dobson H \& Hahnel A 2006 Isolation and transplantation of spermatogonia in sheep. Theriogenology 66 2091-2103. (doi:10.1016/j.theriogenology.2006.03.039) 
Rowell JL, McCarthy DO \& Alvarez CE 2011 Dog models of naturally occurring cancer. Trends in Molecular Medicine 17 380-388. (doi:10.1016/j.molmed.2011.02.004)

Scharf SJ, Smith AG, Hansen JA, McFarland C \& Erlich HA 1995 Quantitative determination of bone marrow transplant engraftment using fluorescent polymerase chain reaction primers for human identity markers. Blood 85 1954-1963.

Shinohara T \& Brinster RL 2000 Enrichment and transplantation of spermatogonial stem cells. International Journal of Andrology 23 (Suppl 2) 89-91. (doi:10.1046/j.1365-2605.2000.00025.x)

Shinohara T, Avarbock MR \& Brinster RL 1999 ß1- and a6-integrin are surface markers on mouse spermatogonial stem cells. PNAS 96 5504-5509. (doi:10.1073/pnas.96.10.5504)

Shinohara T, Avarbock MR \& Brinster RL 2000a Functional analysis of spermatogonial stem cells in steel and cryptorchid infertile mouse models. Developmental Biology 220 401-411. (doi:10.1006/dbio.2000. 9655)

Shinohara T, Orwig KE, Avarbock MR \& Brinster RL 2000b Spermatogonial stem cell enrichment by multiparameter selection of mouse testis cells. PNAS 97 8346-8351. (doi:10.1073/pnas.97.15.8346)

Silva C, Wood JR, Salvador L, Zhang Z, Kostetskii I, Williams CJ \& Strauss JF III 2009 Expression profile of male germ cell-associated genes in mouse embryonic stem cell cultures treated with all-trans retinoic acid and testosterone. Molecular Reproduction and Development 76 11-21. (doi:10.1002/mrd.20925)

Soh BS, Song CM, Vallier L, Li P, Choong C, Yeo BH, Lim EH, Pedersen RA, Yang HH, Rao M et al. 2007 Pleiotrophin enhances clonal growth and long-term expansion of human embryonic stem cells. Stem Cells $\mathbf{2 5}$ 3029-3037. (doi:10.1634/stemcells.2007-0372)

Suzuki H, Sada A, Yoshida S \& Saga Y 2009 The heterogeneity of spermatogonia is revealed by their topology and expression of marker proteins including the germ cell-specific proteins Nanos2 and Nanos3. Developmental Biology 336 222-231. (doi:10.1016/j.ydbio. 2009.10.002)

Takashima S, Kanatsu-Shinohara M, Tanaka T, Takehashi M, Morimoto H \& Shinohara T 2011 Rac mediates mouse spermatogonial stem cell homing to germline niches by regulating transmigration through the blood-testis barrier. Cell Stem Cell 9 463-475. (doi:10.1016/j.stem.2011.08.011)

Takehashi M, Kanatsu-Shinohara M, Miki H, Lee J, Kazuki Y, Inoue K, Ogonuki N, Toyokuni S, Oshimura M, Ogura A et al. 2007 Production of knockout mice by gene targeting in multipotent germline stem cells. Developmental Biology 312 344-352. (doi:10.1016/j.ydbio.2007. 09.029)

Takehashi M, Kanatsu-Shinohara M \& Shinohara T 2010 Generation of genetically modified animals using spermatogonial stem cells. Development, Growth \& Differentiation 52 303-310. (doi:10.1111/j.1440-169X. 2009.01167.x)

Tsai KL, Clark LA \& Murphy KE 2007 Understanding hereditary diseases using the dog and human as companion model systems. Mammalian Genome 18 444-451. (doi:10.1007/s00335-007-9037-1)
Tyagi G, Carnes K, Morrow C, Kostereva NV, Ekman GC, Meling DD, Hostetler C, Griswold M, Murphy KM, Hess RA et al. 2009 Loss of Etv5 decreases proliferation and RET levels in neonatal mouse testicular germ cells and causes an abnormal first wave of spermatogenesis. Biology of Reproduction 81 258-266. (doi:10.1095/biolreprod.108. 075200)

Vassiliev I, Vassilieva S, Truong KP, Beebe LF, Mcllfatrick SM, Harrison SJ \& Nottle MB 2011 Isolation and in vitro characterization of putative porcine embryonic stem cells from cloned embryos treated with trichostatin A. Cellular Reprogramming 13 205-213. (doi:10.1089/cell. 2010.0102)

West FD, Terlouw SL, Kwon DJ, Mumaw JL, Dhara SK, Hasneen K, Dobrinsky JR \& Stice SL 2010 Porcine induced pluripotent stem cells produce chimeric offspring. Stem Cells and Development 19 1211-1220. (doi:10.1089/scd.2009.0458)

Wilcox JT, Semple E, Gartley C, Brisson BA, Perrault SD, Villagomez DA, Tayade C, Becker S, Lanza R \& Betts DH 2009 Characterization of canine embryonic stem cell lines derived from different niche microenvironments. Stem Cells and Development 18 1167-1178. (doi:10.1089/scd. 2008.0336)

Wu X, Schmidt JA, Avarbock MR, Tobias JW, Carlson CA, Kolon TF, Ginsberg JP \& Brinster RL 2009a Prepubertal human spermatogonia and mouse gonocytes share conserved gene expression of germline stem cell regulatory molecules. PNAS 106 21672-21677. (doi:10.1073/pnas. 0912432106)

Wu Z, Falciatori I, Molyneux LA, Richardson TE, Chapman KM \& Hamra FK 2009b Spermatogonial culture medium: an effective and efficient nutrient mixture for culturing rat spermatogonial stem cells. Biology of Reproduction 81 77-86. (doi:10.1095/biolreprod.108.072645)

Yang S, Lin G, Tan YQ, Deng LY, Yuan D \& Lu GX 2010 Differences between karyotypically normal and abnormal human embryonic stem cells. Cell Proliferation 43 195-206. (doi:10.1111/j.1365-2184.2010.00669.x)

Zeng W, Tang L, Bondareva A, Luo J, Megee SO, Modelski M, Blash S, Melican DT, Destrempes MM, Overton SA et al. 2012 Non-viral transfection of goat germline stem cells by nucleofection results in production of transgenic sperm after germ cell transplantation. Molecular Reproduction and Development 79 255-261. (doi:10.1002/ $\operatorname{mrd}$.22014)

Zeng W, Tang L, Bondareva A, Honaramooz A, Tanco V, Dores C, Megee S, Modelski M, Rodriguez-Sosa JR, Paczkowski M et al. 2013 Viral transduction of male germline stem cells results in transgene transmission after germ cell transplantation in pigs. Biology of Reproduction $\mathbf{8 8} 27$. (doi:10.1095/biolreprod.112.104422)

Received 4 March 2013

First decision 8 April 2013

Revised manuscript received 6 May 2013

Accepted 20 May 2013 